\title{
Anaerobic metabolism of the ribbed mussel, Geukensia demissa
}

Ming-Shan Ho

College of William and Mary - Virginia Institute of Marine Science

Follow this and additional works at: https://scholarworks.wm.edu/etd

Part of the Biochemistry Commons

\section{Recommended Citation}

Ho, Ming-Shan, "Anaerobic metabolism of the ribbed mussel, Geukensia demissa" (1980). Dissertations, Theses, and Masters Projects. Paper 1539616696.

https://dx.doi.org/doi:10.25773/v5-nzaa-tz71

This Dissertation is brought to you for free and open access by the Theses, Dissertations, \& Master Projects at W\&M ScholarWorks. It has been accepted for inclusion in Dissertations, Theses, and Masters Projects by an authorized administrator of W\&M ScholarWorks. For more information, please contact scholarworks@wm.edu. 


\section{INFORMATION TO USERS}

This was produced from a copy of a document sent to us for microftming While the most advanced technological means to plotograph and reproduce this document have been used. the quality is heavily dependent upon the quality of the material submitted.

The following explanation of techniques is provided to help you understand murkings or notations which may appear on this reproduction.

1. The sign or "target" for pages apparently lacking from the document photographed is "Missing Pagetsy". If it was possible to obtain the missing pagets] or section, they are spliced into the fitm along with adjacent pages. This may have necessilated cutting through an image and duplicating adjacent pages to assure you of complete continulty.

2. When an image on the film is obliterated with a round black mark it is an indication that the film inspector noticed either blurred copy because of movement during exposure, or duplicate cupy. Unless we megnt to delete copyrighted materials that should not liave been filmed, you will find a good lnage of the page in the adjacent frame.

3. When a map, drawing or chart, etc., is patt of the material being photographed the pholographer thas followed a definite me thod in "sectloning" the material. It ls customary to begin filming at the upper left hand corner of a large sheet and to continte from left to right in equal sections with small overlaps. If necessary, sectioning is continued again-beginning below the frirst row and continuing on until complete.

4. For any illustrations that cannot be reproduced satisfactorily by xerography, photographic prints can be purchased at additional cost and tipped into your xerographic copy. Recuests can be made to our Dissertations Customer Services Department.

5. Some pages in any document may have indistincl print. In all cases we have filmed the beyt avallable cupy.

\section{Universty \\ Microtilms Intemational}

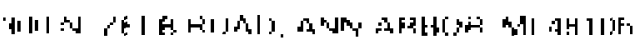

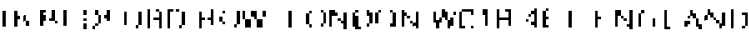


Ho. MIRig-SriAs

ANAEROBIC METABOIISM OF THE RIHHEJ MUSSFL., GEUKENSIA DEMISSA

\section{University}

Microfilms

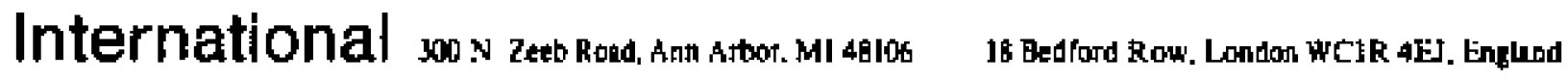


AKAEROBIC METABOLISM OF THE

RIBBED MUSSEL, GEURENELA DEMSSA

A Diggertation

Pregented to

The Faculty of the School of Marfne ScLente

The College of W1llan and Hary in Virginta

In Partial Fulfilment

of the Fequirements for the Degree of

Doctor of Phtlogophy

\author{
by \\ HIng-5hen Ho \\ 1980
}


APPROVAL SHEET

Thia diagetation 1 s abutted fo partial fulfiliment of the requiremente for the degree of

Doctor of Fh1losophy

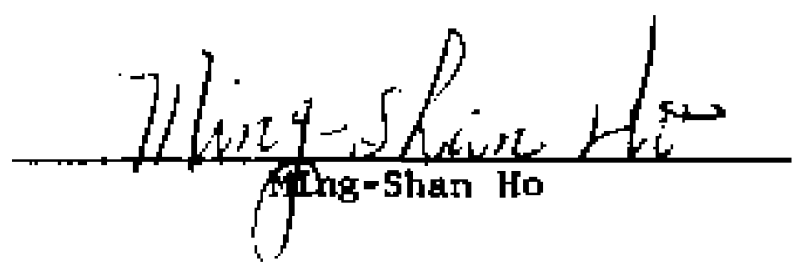

Approved, Aprt1 1980
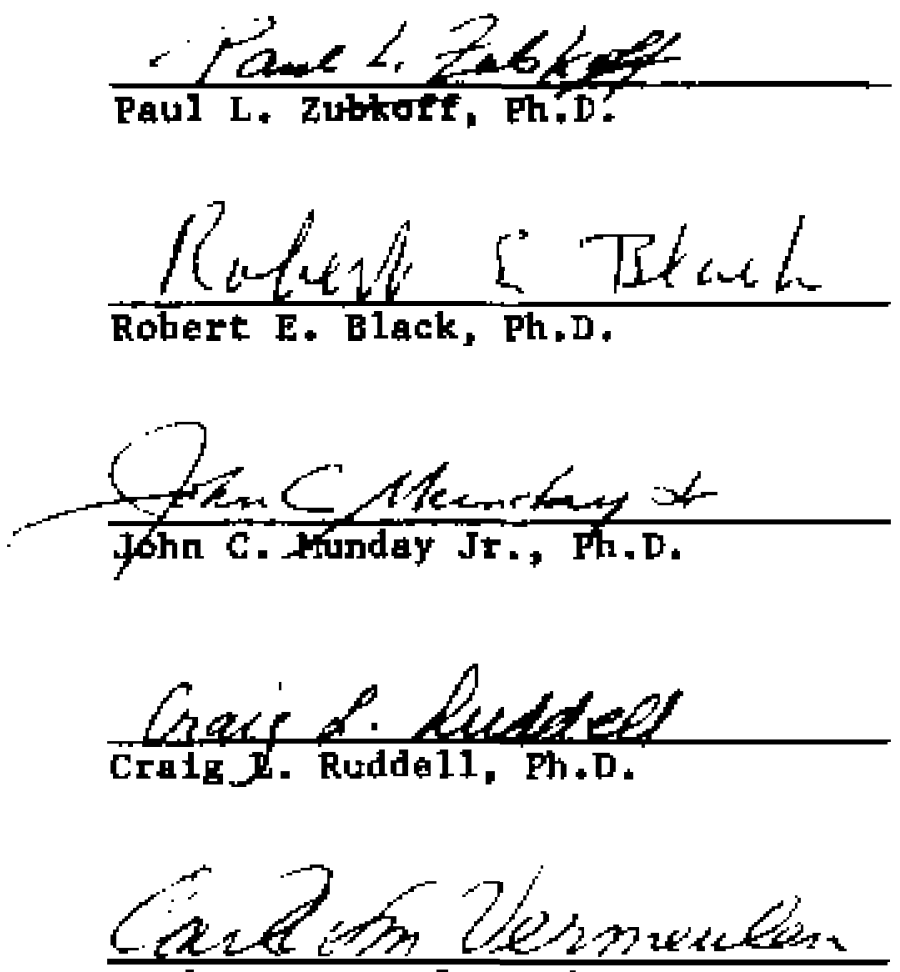

Car1 W. Vermeulen, Ph.D.

Department of B1ology

college of Willian and Hary in Vtrginta 
TABLE OF CONTENTS

Page

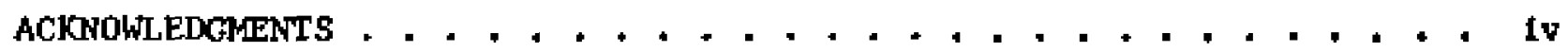
LIST OF TABLES , + . . . . . . + . . . . . . . . . . . . . . . v

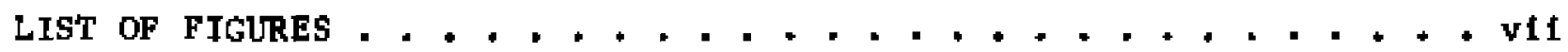

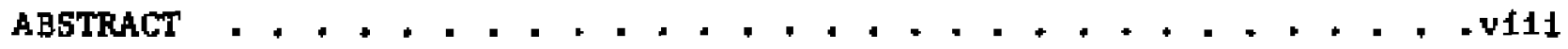

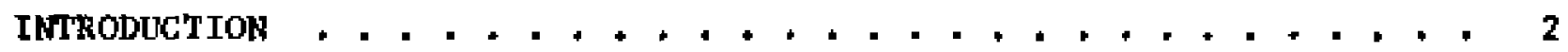

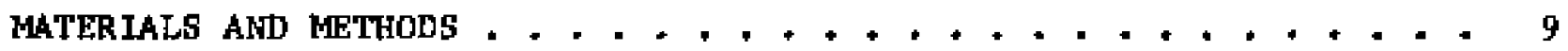

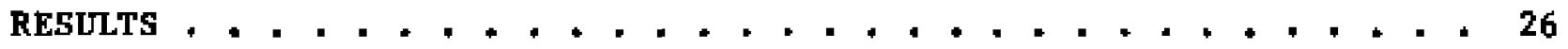

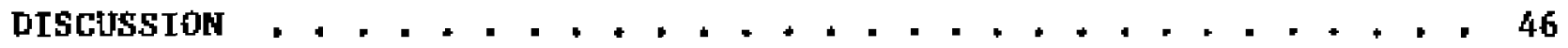

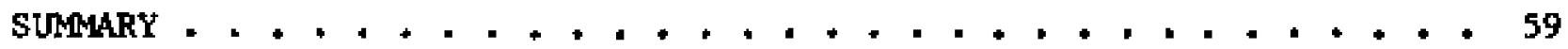

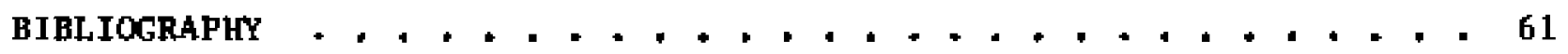
APPENDIX +................................ 67

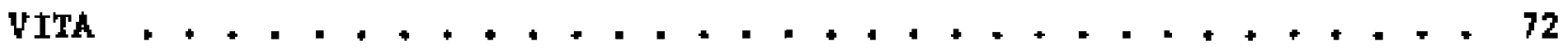




\section{ACKNONLEDGMENTS}

The author wiahes to exprega his apprectation to Dr. P.L. Zubkoff for hig invaluable edvice, training and encouragement throughout the courge of thig atudy. His gratitude 19 aloo extended to other menbers of the commitcee, Drg. R.E. Black, J.C. Munday Jr., C.L. Ruddell and C.W. Verneulen, Thanks are also due to Mr. J.E. Wartnner, III, Drs, R, Jordan and A.L. Lfy for their unfotgettable friendship, agatgtance and encouragement and to Dr. C.P. Mengum for her helpful digcussion. The author is also grateful to Mre. L.L. Jenk1ng and Mra. L.T. Marehall for typing this dissertation and to peraonnel in the library and in the graphic arts and photography aection of this Inatitute for their constant help is preparation of thita manuscrtpt.

The author apprectates the research agalotantship provited by Dr. M.E. Bender, Head of the Division of Envtrotmentel Sclence and Englneer Ing. WLginla Institute of Marine Science.

It 1. wo difficult to dencribe the deep appreciation and affection of the author to his parents, wife, brocher and gister, without their help, thla work would gever be posalble. 


\section{LIST OF TABLES}

TABLE

PAGE

1 A Chronology of Mollugcan Anaeroble Metaboligm , . . . . . . . 3

2 Methods for the Aralye1e of Key Metabolites and

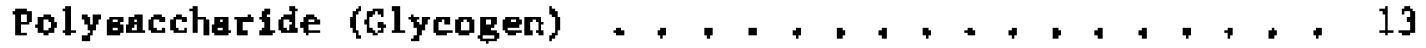

3 Standard Mixture of Ktebs Cycle Intermedlates . , . . . , 17

4 Recovery of a Standard Mixture of Krebs Cycle Intermediateg - 20

5 Detector Response Factors of Free Volatile Aclda a Decermined In a Standard MLxture . . . . . . . . . . 22

6 The Concentrations of Krebs Cycle Intermediateg of Varloug Tisaves of the Oystet, Cragsogtren Verginice

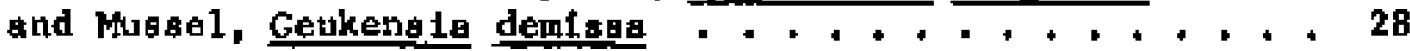

7 Concentratlons of Polybaccharide and Key Metabolitea of Geukengla demlaga Aftar inta lnirg at $15^{\circ} \mathrm{C}$ for 51 Houre Hith Aerated River Hater (December 1978) . . . . " 32

8 Concentrations of Bolyaaccharlde and Key Metabolites of Geukeng la demlege After 51 Houtre of Hypoxta (December 1978) ..................... 33

9 Concentrat Ions of Polyaaccharlde and Key Vetabol tte of Geukensia demilan After Maintatulng Under Oxygen and NAtrogen at $15^{\circ} \mathrm{C}$ for 51 Hourg (December 1978) . . . " 34

10 Concentrationg of Polybaccharide and some Mecabolites of Geukeng La derisag Collected at Low TIde (June 1979) . . . 36

11 Concentrationg of Polyanccharide and Some Metabolites of Geukengla demiaga After Two Days Acclimat lon at $15^{\circ} \mathrm{C}$ Hits Aerated River Hater (June 1979) . . . . . . 37

12 Concentrations of Polyaaccharlde and Key Wetabolices of Geukengla demisea After One Day of Hypoxta (June 1979) , 38

13 Concentrationg of Polygaccharide and Key Metabolitea of Geukensia demiaga After Two Days of Hypoxia (June 1979). 
LIST OF TABLES (cont'd, )

TABLE

PAGE

14 Concentratione of Polyaaccharide and Key Metabolites

of Geukengla demtega After Three Days of Hyponia

(June 1979) ........................440

15 Concentrations of PolygaccharLde and Key Hetabolites

of Geukengla demigan After Four Days of Hypoxia

(June 1979) , ........................ 41

16 Average Concentrationg of Polyaccharide and Key Metabolites

of Geukenta demlaga After Fleld Collection (-2 Days), Two

Days Acclimation (0 Day) and One to Four Days of lypoxia . . 42

17 Average Concentrationg of Succlnate, Prop Longte and Alanine

of Musalo, Geukengla demige After Fleld Collectlon

(-2 Days), Two Dayg of Acclinution ( 0 Day) and One to

Four Daya of Hypoxta . . . . . . . . . . . . . . . . 43

19 The Aceimulation of Succinate, Proplonate, Alanine and Lactate During Anaerobiosis of Several Btvalve Spectes * * 49

19 Concentrations of Polysaccharfde end Some Hetabolitea of WLnter (Dacenber 1978) and Summer (Jume 1979) Musge1s, Geukensia demleas, After Two Daya of Hypoxia . . . . . . . 49

20 Krebs Cycle Intermediateg In Repreaentat 1ve Organiems *.... . 51

21 Balance Sheet of Anaerobic Metabolian of Geukengla demisaa According to the Hypothetical scheme .. . . . . . 57 
1 Four Major Anaerobic Metabollc Schemes , + +,$\ldots+\ldots$

2 Fractionation of the Fibbed Mugsel, Geukengia demigge . . . . 12

3 Preparation of Kreba Gycle Intermedfates for Gag-Liquid

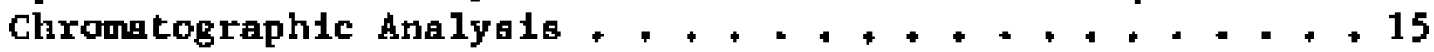

4 Gas-LIquid Chropatography of Methyl Eaters of Krebs Cycle Inteimediater of Oyater, Crageogtrea virginica . . . . . . 27

5 Gas-Liquid Chromatography of Methyl Eaters of Krebs Cycle Intermed lateg of Mhas , Geukengla demLas . . . . . . . 30

7 The Ttme Dependent Accumulation of Succlnate, Proplonate and Alanine 1n Geukenela demiaga . . . . . . . . . . . . . 44

8 A Hypothetical scheme of Geukengle demigea

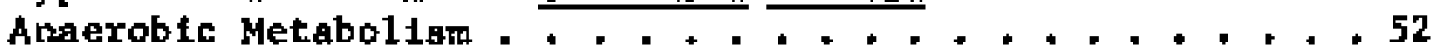




\section{ABSTRACT}

The anaerobic metaboligm of the Intertidal ribbed muagel, Getakena demigna (x Modtolug demLaus), Is reported in this disertation. This tollugc was aelected because anaeroble metaboliam le belleved to be of vital olgnificance to tta ourival duting the alr exposure period of the tidel cycle.

RAbbed mugela, Geukeng 1a demlaga, were malntalned 1n either aerated or hypoxic water for up to four daya. Hajot metabolites and polyancchartde of each mugel were then analyzed and compared. Succinate, propionate and alanthe were found to eccumiate hypoxtcally, but not malate, a-keto-glutarate, cls-aconitate, cttrate, Loo-butyrate, butyrate, lao-valerate, lactate and pyruvate. The potysacchar Ide content of each musael was quite different and did not show e clear Indication of decreese under the hypoxte condition.

Proplonate production followed aucc lnate accumulation, which corroborateg an earlier report for tytilus edu110. The linear increase of alanine concentration with hypoxic pertod obaerved In this atudy, has not been reported prevlougly.

The reaulta of this gtudy are consigtent with those of pyt1lug edulig, Cardium edule, and Anodonta cyghea, blvalveg which heve recently been studied In Europe. This agreenent guggegte thet bivalves haye a gmilar anaerobtc tietabolto scheme.

A hypothetical gcheme of anaeroble metaboltem of blvalvea $\mathrm{Ia}$ propoed In thich redox balance $I_{s}$ achleved tn both cytogol and attochondr la. ThIg ocheme Incorporaceg parta of the Embden-Meyerhof-tarnas glycolytic pathways, carbon dtoxide fixation, the Krebs cycle, trangamination, and pathway for proplonate formation. To date, this ls the only bivalve anaeroble acheme which containg all thege egential considerations. 
alHAEROEIC METABOLTSM OF THE

RIBBED MUSSEL, GEUKENSLA DEMISSA 


\section{INIRODUCTION}

The ablitey of molluaca, auch as Sydoamy alta, to 1 IVe in deoxygenated water and ourvive for tore than three days has long been recogolzed (Moore, 1931). Thfo capabilfty for many mollugce to gurvive under a condtion of low oxygen avallability not only allowg them to withetand a temporary anoxic condition but aleo enables ther to function in the oxygen deficlent habitats for at leagt part of their lifa cycle (Theede et al, 1969). It to probably important for the Intertidal blvalves becauge they may not be able to extract enough oxygen ftom the alr to augtaln aerobic metabolifon. The ribbed musel, Gaukensta demlaga (= Modiolut dentogug) which dwe1la In the high Intertidal zone and Is abundant along the atlantic coast of the Uniced Stateg 1a a good example of such an organistn. Geukengla demigsa are usublly found in clumpe among toote of cardgrase, spartina op., half embedded In the mud of eflt marabes (Lent, 1967). During afr expogure, the1t rate of oxygen consumption 1 reduced (Kuenaler, 196:; Hiddowa et al, 1979) and the primary pathways of metabolism In the deep tianue are belleved to be anaerobto becauge their oxygen transport aysten ig ineffictent (Booth end Hangum, 1978).

The recent progreag of underatanding molluscan anaerobic metabolian Ia briefly preaented In Table 1. In the freahwater gatropods atudied by Von Brand at al. (1950) and Hehlman and Von Brand (1951), lactate and volatile fatty actda were found to accumilate naerobloally. Bivalve anaeroblo wetabolfam was not Imveatigated In detall until De Zwan and his collabotator 
A ERRONOLOGY OP MOLLUSCAN ANAEROBIC METABOLISM

I. Freah Hater Geatropoda

A. Netabolite and Iys Is

Afiox le condition

Lactate accumulatton

Anoxtc condtition

Frop lonate and acetate accumulation
Lymneea Btagnalig

Lymnea natalenaIs

Augtelorbig

slabratus

Hellsoma dury1
Von Brand et a1. 1950

Mehlman and Von Brand 1951

Hammen, 1966

Wantle of oy
Crageostreg

viritnica

Mantle of clatu

Rang Lo cuneatta

ar end producte of

14C-g Iucdue (U)

degradation

B. Enzyre activity atudtes

Anoxic condition

Fumarate reductabes Succ tnete dehydrogerage

Anoxte condition

PEP carboxykinane ?

Pyruvate kinage

c. Hetebolite aralyois

Anoxic conditton

Succlnate and alanine

accumulation

Anoxtc condtion

Volatile fatty aclds:

accumulation
Oygter

Cragagatrea

virglntea

Adductor muscle of oyter

Cragtostrea RLgan

Hug ce 1

Nyt1lue edul1日

Hug ae 1

Hyc1lug edulis
Stokes and Awapara 1968

Wegener et 브, 1969

Hochachka and Hutafa, 1972
De Zwoan and

Zandee, 1972b

Kluytmang et 르. 1975 
employed the methoda of metabolite anflysis. They found that succinate, alantre (De Zwan and Zandee, 1972b) and volatile fatty acida (Kluytmanta et al*, 1975) accumulated when Bea musela. Mytilug edulis, were held under 4 controlled anaeroble condition. Sone earlier gtudieg aloo atggegted the accumulation of aucclate and alanfne, aa well ag a reveraal of part of the Krebs cycle which tncorporates carbon dloxide dur Ing bLvalve anaeroblc metabol1em:

phosphoenolpyruvate $+\mathrm{CO}_{2} \rightarrow$ oxaloacetace $\rightarrow$ malate $\rightarrow$ fumarate $\rightarrow$ succlnate (Kammen, 1966; Stokeg and Awapare, I968; Hegener eㅡ al., 1969; Hochachka and Mistafa, 1972). The moat recent work on anaeroble metabolism ut 11 faed yyt1lye edul1g (De Zwaan and Zandee, 1972b; De Zwaan and Harrew1jk, 1973a, b; De Zwaan et eㅗ., 1973; Loxton and Chap11n, 1973; k1uytmans et aㅡ, 1975; De Zwaan eㅡ al., 1975; Kluytmang and De Zwaan. 1976; KLuytmans et al., 1977; W1ddows et al., 1979), Cardlum edule (G̈̈de, 1975), and Anodonta cygnea (Gäde et al., 1975). Feactions conglatent wth a imllar anaeroblc metabolic scheme have alao been found In auch other tnvertebrate organigms ag the gea anemone, pladumene leugoleng (E111ngton, 1977), the olfgochaete, Tubtfex ep. (Schöttler, 1975, 1977a, b, 1978; Schöttler and Schroff, 1976), the polycheetes, Arentcola arina (Zebe, 1975; Surho1t, 1977) and Lumbricus ap. (Gruner and zebe, 1978), and the 1ngect, Chtronomug sp. (Augenfe1d, 1966 ; wLlps and Zebe, 1976).

Four majar achemeg of angeroble metabollam have been observed and are herein deglgnated (Figute 1) as

(A) lactate fermentation: mammis and ectme paragitic wotms (Schlotoscha manepot) ;

(B) ethenol fermentation: yeagt: 
FIQURE 1. FOUR MAJOR ANAEROBIC METABOLIC SCHEMES. 
FOUR MAJOR ANAEROBIC METABOLIC SCHEMES

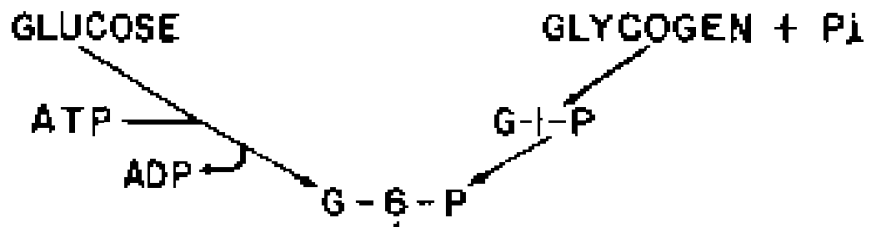
(A) LACTATE FERMENTATION
(Mommals and Parasitic worms,
Schishosamamonsoni)

(B) Ethonol Fermentotion ( Yeosis ]

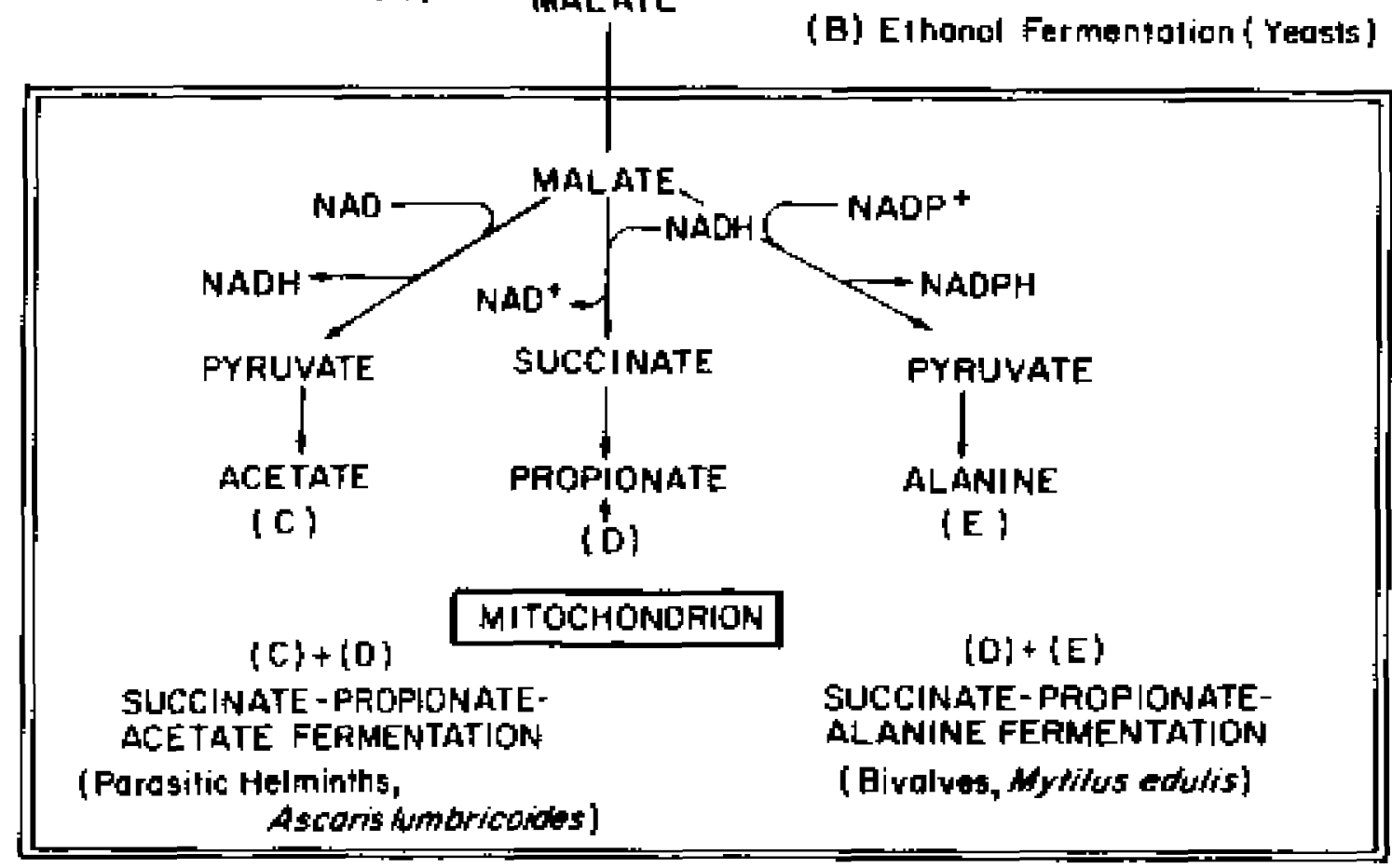


(C + D) aucctnate-prop lonate-acetate fermentation: parastic helminthe (the pig roundworm, Ascerte lumbricoldes [reviaw: Saz, 1969, 1970, 1971]); and

$(D+E)$ aucclate-proplonate-alanine fermentation: bivalves treview: De Zwaan et 브, , 1976; De Zwaan and W1jeman, $1976 ;$ De Zwan, 1977 ].

of the three major metaboliteg which accumulate durlug bIvalve anaerobic metaboliam (Guccinate, proplonate, and alanine), the formation of succinate through a reveraal of part of the Krebs cycle oxaloacetate $\rightarrow$ mala $\rightarrow$ fumarate $\rightarrow$ acclate 1s accepted; proplonate 1a probably geherated by the decarboxylat Lon of succlnate (Tkachuck et aI*, 1977; Saz et al*, 1978); and the or Lgtn of alantne Is et1ll controveredal. Stokes and Awapara (1968) augsegted that 1n Rang La chneaca, the alanine accumblated durtng anaeroble thetabolism wea formed by trangamination of pyruvate whth amino aclde. Such tranamination reactiona were also shown for Geakengla demlean and yytilua edulia by kead (1962). Later, Hochachka and his collaboratorg further postulated that during molluacan anaerobloats, amino acids were gimultaneously mobilized with carbohydrates In order to generate energy and malntain redox balance (Hochachka and Hustafa, 1972; Hochachka and 5omoro, 1973; Hochachke et al., 1973 ; Hochachka, 1976; Collicutt and Hochachka, 1977). However, De Zwadn and his coworkers found that alanine probably only accumlated intelally; they diaputed both the trangamination orlgIn of alarine and the sLuultaneoug mobil-

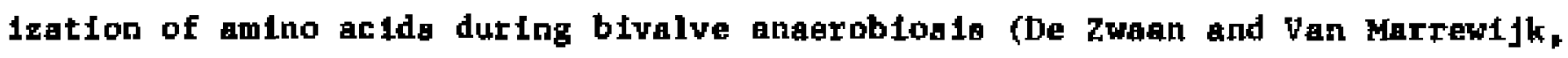
1973a; Gade ete aㅡ., 1975; De 2waan eㅡ al*, 1975; De Zwaan et a1., 1976;

De Zwash and H1Jaman, 1976; De 2wagn, 1977; Kluytmans et a1, 1977). They pregented no alternative explanation, and tranamination was atfil proposed A6 the source of alantne In thetr metabolic pathway (De Zwaan et e1.. 1976). 
Ao mentioned previaugly, the preaent concept of mollugcan anaerobic metabollem was egtabliahed by De Zwaen and bib collaborators with atudies predominately undertaken with Mytilug edullg. Although thege Interpretathons are Impressive, te is ot11: very useful to have the regulta confirmed Independently by other Imvegtigatorg with different analytical bethoda and on different bivalve apectes. Thus, the major objectives of this disgertat Lon are:

(1) To extend the apecific observations on the European bivalve, sytilus edulfs, to another species. The ribbed mose1, Geukensta demiegs, 1o chogen for this atudy because te lo ecoloffcally and phyetologically Interesting and it is taxonomically related to Myt1lug edu11투

(2) To compare the reoults of Geukengla demLaga to those dertved by De zwan and ble asochateg fn order to general1ze observations on the anaerobic metaboligt of biralvea;

(3) To atudy the functiona of the Krebs cycle Intermediatea (1ncluding aucelngte) In bivalve anaerobte metabol Lag wth the oengitive gas-liquid chromatographlc method Which analyzes beven tncetwediater atmltaneously; and

(4) To clarify the argument about the role of alantge in bLvalve aneeroble metaboliam.

To achieve theae goals, wisgelo were wafntalned under controlled high and low oxyben tensions. Each mussel was then extracted, agsayed and com= pared for concentrationg of polyeaccharlde, Krebs cycle Intermediatea, 
volatile fatty aclda, alanIne, lactate and pyruvate. To date, this to the firat otudy of bivalve eraeroble metaboliam in which a11 such Intermediateg were meatured In ind Lvidual organions ingtead of pooled tigatues. Defined terms and thme courge btudies were condueted using mugels under both winter and ourwer conditions.

The regulte of metabolfte accumliationg determined in this gtudy were Integrated wth exlating knowledge of enzyme localixatlon, kfnetica, and regulation and a hypothetical metabolic scheme is proposed. This gcheme takes Into account cytogol-mitochondrial compartmentat1on, a modifled EmbdenMeyerhof-Parnas glycolyttc pathway, carbon dioxide fixation, the Krebs cycle, pathways for proplonate and alantne formation, and it attalna redox balance overa11. This acheme of blvalve anerable metaboltan may agatet in the deAign of further reftnements in the understanding of the metabolic control of bIvalves. 
MATERLALS AND METHODS

In order to quantify the numerous intermediates potentially involved In Intermedlary netabolian, aeveral analytical techniqueg were necebary. These tncluded derivatization, gas-11quld chromatography and ultraviolet spectrophotometry for enzyme enalysi, Intelal testing of aome of these procedureg in order to develop technique and vertfy the method was accomplished using another wollusc, the oyster, as a tegt organtam for extractione,

Oyeters

Dyatero (Cragoogtreg virgintcg) uaed in this atudy were three yeare old, $11.0 \pm 0.5 \mathrm{~cm}$, approximately $20 \mathrm{~g}$ (tieaue wet welght) and were predetermined to be healthy and superficially free of paragtes, They were cultured from larolal atage at Virginia Ingtitute of Martne sctence, Gloucester Polnt, Verginla and malntalned on a tray in the adjacent York River with oa11nity from $16-21 \mathrm{o} / 00$.

Mugenela

RLbbed nubels (Gabengla denlagg) wth ohe11 lengthe of $11.5 \pm 1.0 \mathrm{~cm}$ were collected on the bank of York River near Muford Island, Virginia. The average wet weight (Including encloged gea water) was $89.6 \mathrm{~g}$ and the dry weight was $2.95 \mathrm{~g}$. Before each experiment was atarted, the bivalves were placed th glass deficcatorg wth aerated York River water and acclimated at $15^{\circ} \mathrm{C}$ for two days. The temerature was matntained rith circulattng water 
held congtant with a Lo-Temptrol 154 water circulator (Preciaion Scientifle Co., Chtcago, I11fnota).

\section{Expertmente}

Two exper Imental reglmeg were cartled out: (1) Fixed term otudy: After acclimation, elght musels were randcinly divided into normoxic and anoxtc aete and incubated for 51 houre. Incubation was carried out th December 1978. (2) Time courae gtudy: 23 mugaels were randonly chosen for the following treatmenta: elght were gacriflced tmediately after fleld collectLon; three after two days acclingtion; and the retalnfing magelo were Incubated anoxtcally for pertode up to four daya, with groupa of three mus8els each aacriflced dafly. This experiment was atarted in June 1979.

\section{Incubat fon}

For the anoxle condtion, the river water medium contaloing musels was flughed wteh nitrogert gag (Unton Carbide Co., Linde Diviaton, N.Y.). The alr trapped under destcoator topg was also replaced with nitrogen gas before gealing. The concentrationg of dLsolved oxygen for normoxic water was at least $4.2 \mathrm{ppm}$ for the fixed term atudy, and $7.0 \mathrm{ppm}$ for time courae gtudy; diegolved oxygen was below $0.4 \mathrm{ppm}$ for anoxtc water as determined by both, polarographle measurement wth an oxygen meter (Hodel 51A, Yellow Springs Instrument Co., Yellow Springe, ohlo) and Hinkler titration. The galinity of the river water meditm wa determined to be 17.1 o/oo with a Beckman RS-TB Induction ealinomater for the mlxed term study and 14.4 o/oo fot the time courge atudy. The Incubation temperature was $15^{\circ} \mathrm{C}$ and the organtimg tere not fed during the experimenta, After tncubation, the wusaela were quickly ramored from the deglccator, the1r atgeg and total welghts were measured and then the organtmo were etther frozen (for fixed term 
gtudy) or opened under a etream of nitrogen gas and qulckly frozen in dry lce-acetone (For time course atudy) before further treatmento.

\section{Preparation of Hompgenates}

The frozen misgels were opened and thelr contents collected; the whole process tras rapld and the tigaves were watnta1ned cold with tce water. Thase preparat long which were elther malntalned cold or frozen with dry loeacetone were minced with actagorg and homogenized wth a cold buffer of 2amino-2-methyl-1-propanol (0.1 $\mathrm{K}, \mathrm{pH} 10, \mathrm{Stgma}$ Chemleal Co.) uglug elther a hand homogentzer or a VIrTfe 45 homogenlzer (Gardiner, N.Y.). Preparat Lab from each mugel were adjugted to 60 ml with buffer and then divided into get: for vartous determinations (ELgure 2). Homogenized fractions were promptly deproteinfed or treated according to the apptopriate procedure for each analyalis and gtored. The anelytical methods are aumartzed 1n Table 2.

Dry Weight Determinat Lon

Aliquots $\{10 \mathrm{~m} 1)$ of musel t1gave homogenate were trangferred to tared aluminum containera, dried at $60^{\circ} \mathrm{C}$ for 24 houra and then watnatned in vaculm dealccator over phoaphorug pentondde for three daya * Samplea were welghed with an analytical balance.

\section{Folyoacchar Ide Detetmination}

Polyaccharide was teolated according to the method of De Zwaan and

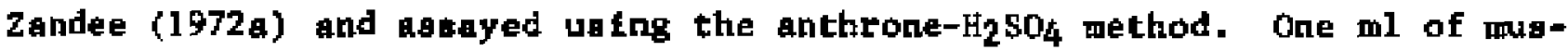
oel houggenate deafgnated for potyeacchatide determination was aponified In one onl of $50 \%$ kOH for one hour at $50^{\circ} \mathrm{C}$, nettralized wth $\mathrm{kC} 1$, deprotelnlzed wth $0,06 \mathrm{~g}$ of trichloroacetic actd and centrifuged for 20 minutes 
병

是

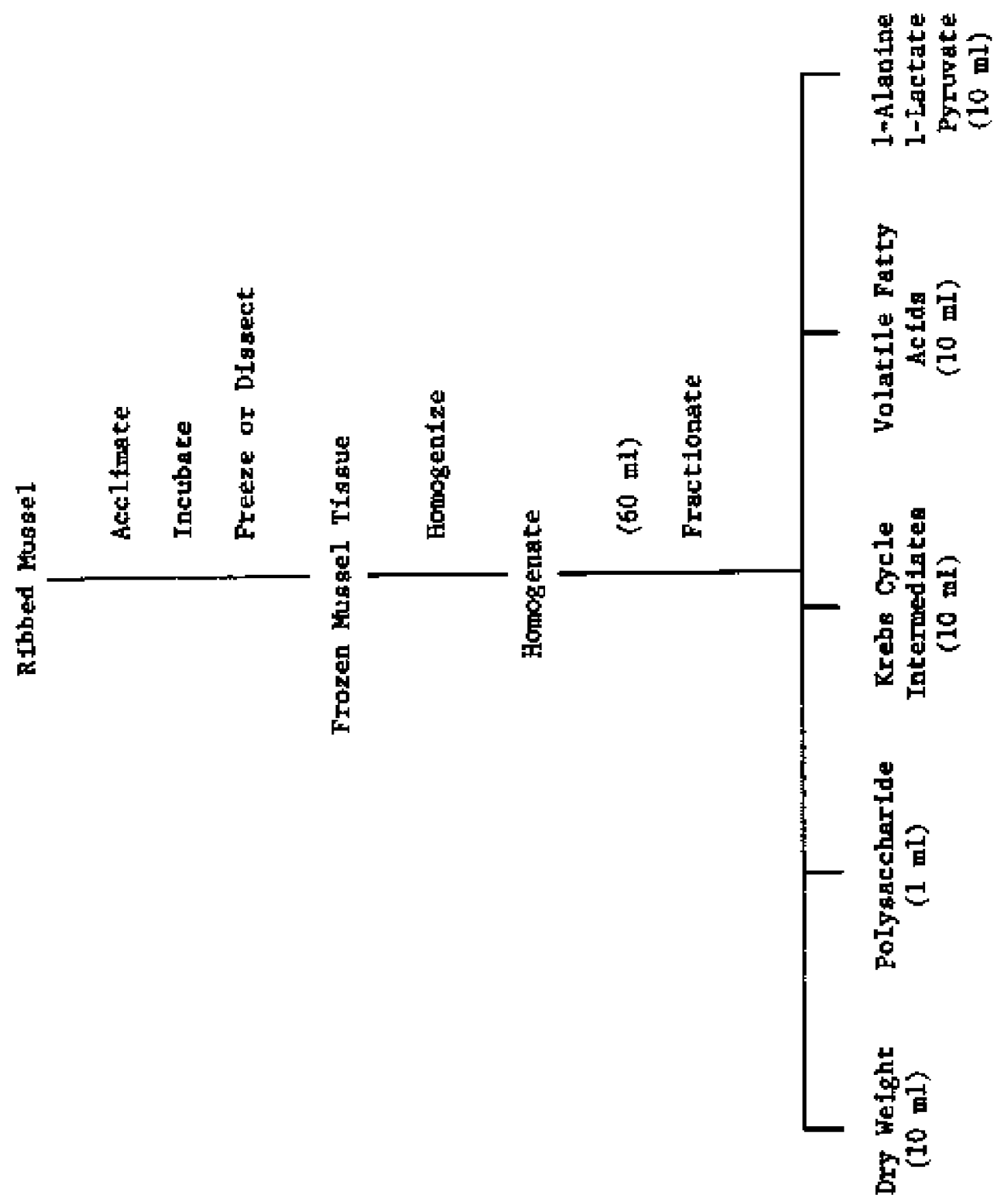

围

鸟 
TABLE 2

METHODS POR THE ARALYSTS OP

KEY METABOLITES AND POLYSACCHARIDE (GLYCOGEN)

COMPOUNDS

ARAI.YSIS

Kreba Cycle Intermediates

De Sflva (1971)

Volatile Fatty Acids

GIbbe et al. (1973)

Alanine

Schutgen et eㅡ * (1977)

Lactate

Stgma 826 tN (1977)

Pyrurate

S1gma 726 w (1977)

Polyeacchar tde

De Zwan and Zandee (1972)
Celiter and BasLe Aluntna

Colun Puriftcation

BF 9-Methano1 Der Lratization

solvent Extraction

Gas-1 Lquid Chromatography

Ferch1orate Deprotein1zation

KOH Precipttation

Solvent Extraction

Ges-1Iquid Chromatography

Alantne Dehydrogenase $\mathrm{MAD}^{+} \rightarrow \mathrm{MADH}$

Spectrophotometry

Lactate Debydrogenage $\mathrm{NAD}{ }^{+}+\mathrm{MADH}$

Spectrophotonetry

Lectate Dehydrogenage

NADH + NAD ${ }^{+}$

Spectrophotonetry

Anthrone Reaction

Spectrophotometry 
wth a clfalcal centrffuge (International Equipment Co, Hag,). The volume of supernatant was meagured and diluted 10 and 100 fold; one mi of each dilution was used for polyaccharide determination.

Preparatione from previous treatments were etirred with 0.05 mi of saturated $\mathrm{Na}_{2} \mathrm{SO}_{4}$ aolution, followed by three ml of ethanol. Samplea were heated In a bołling water bath for three minutea, cooled in an lce bath for at least one hour, and centrifuged; the ethenol was carefully decanted. The polyaccharide pelleta obtalned fter drying with nitrogen gas were dianolved wht 0.05 ml of HzO and 4.0 ml of fregbly prepared anthrone reagent was then added; the mixture was vortexed, heated at 9000 for 20 minutes, cooled In Ice water and meagured at 620 nu wth the Cary yode 15 epectrophotometer. Anthrone reagent was prepared by disgolvtng 0.25 g anthrone in 100 w of cortcentrated aulfuric acid.

Krabs Crcle Intermediates Determination

The Krebs cycle Intermedlates were toolated (Flgure 3) and ueasured according to the method of de st1va $(1971)$.

A. Reagents

The Krebr cycle tatermediateg, adiplc actd and bagle alumfra (activity grade I) were obtained from SIgma Chemical Co. (St. Lovit, Ko,), Celite 545 from Flaher Sctentific Co. and boron trifluoride-methancl (BF J-HeOH, 14\% w/W) from Applied Selence Laboratortes (Scate College, Pa.). All organte golvente were ana1ytloal gade and redletilled In glage before uae. HF-HeOH (77) was prepared by dilution of a $14 \%$ colution with dry methanal. The internal scandard, dimethy1 adipate, was prepared by reacting 25 mg of adipic actd wt th 10 w1 of $7 \mathrm{~h} \mathrm{BF}_{3}-\mathrm{HeOH}$ at $60^{\circ} \mathrm{G}$ for two houra, cooling to rocm temperature and then adding an equel wolume of water, After extracting the reaction mixture twice 
FIGLRE 3. PREPARATION OF KREBS CYCLE INTERMEDIATES FOR GAS-IIQUID CHROMATOGRAPHIC ANALYSIS. 
PREPARATION OF KREBS CYCLE INTEAMEDIATES FOA GLC ANALYSIS

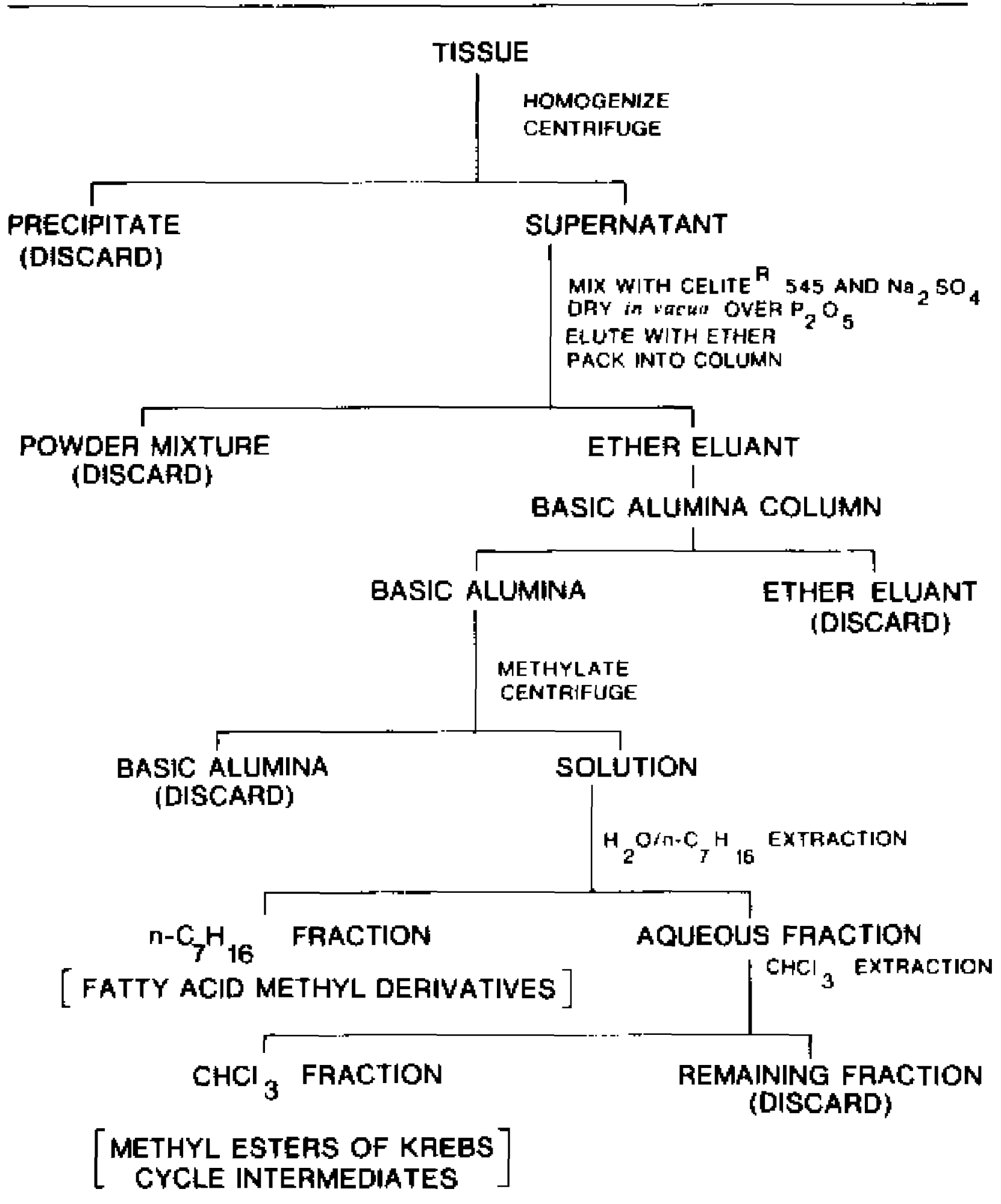


wtth $50 \mathrm{ml}$ of thloroform each the, the comblned extracts were dried ovet anhydrous $\mathrm{Na}_{2} \mathrm{SO}_{4}$ and then the volume Ieconstituted to 100.0 ml with chloroform.

\section{b. Extraction}

Ten ml each of mugeel tlegue homogenate, glase digtilled water (blank contro1), and etandard actd mixture were uged. The gtandard actd mixture was prepared by diagotving the weighed compoundg (Table 3) in 200 ml of 5N $\mathrm{H}_{2} \mathrm{S0}$ : water;methanc $1(1: 3 ; 16 \mathrm{v} / v / v)$.

\section{c. Purification of Tigave Extractg}

The crude acld extract was mlxed thotoughly with $10 \mathrm{~g}$ of ether-washed celite 545R. The molat celtte tag mixed with 10 gof anhydrour Na2504 and atored overnight in a desiccator containing $\mathrm{P}_{2} \mathrm{O}_{5}$. The reaulting powdered mixture was traneferred to a $1 \mathrm{~cm}(1, \mathrm{c}.) \times 50 \mathrm{~cm}$ gtag chromatography columr 1n approxtontely 2 g portiong and packed tightly, The orbanie actda were eluted from the caltnm with ether (approximfely 100 ml). The eluant was: then pasaed through a one g colimn of actlvated basic alumina cxtde (activated by heating in an owen at $100^{\circ} \mathrm{C}$ for two hours and cooling to room temperature). The alumina was drled under a strenm of oltrogen gas, and repeatedly waghed wh acetone five thes and ether twice to completely remove the molatute. The free acida retalned by the alumina were convetted to their methyl esterg by heating with 5 ml of $\pi_{\%}$ BF-MeOH to $600^{\circ}$ for two hourg In a gcrew-capped tube.

Following methylation, the mexture was cooled to room temperature, flitered, and an equal volume of water was added to the filtrate. The film trate contalned methyl ester of fatty aclda and Kreba cycle intermediatea; the fatty acid methyl eoter were removed by waghing the methanol-nFj-weter 
TABLE 3

STANDARD MLYTURE OF KREBS CYCLE INTERUEDTATES

INTERMEDIATES

AHOLNT (mg)

Fumarate

5.0

Succ inate

5.0

Malate

30.0

a-keto-Glutarate

15.0

cto-Aconftate

5.0

Citrate

20.0

Lao-Cterate (tri-godim: aalt)

50.0

A11 anples were homogentzed with 20 fl of $5 \mathrm{~N}_{2} \mathrm{SO}_{4}$ : thethanol (1:19 $v / v)$ In an tee $b$ ath and then centrifuged. The reatdue was agatn homogented wth 10 ml of $5 \mathrm{NH}_{2} \mathrm{SO}_{4}$ : $\mathrm{H}_{2} \mathrm{O}$; thanal $(1: 3: 16 \mathrm{v} / \mathrm{v} / \mathrm{v})$, centrffuged and then gtpergatanta were combined and reduced by a atrean of nitrogen ges to approximitely $10 \mathrm{ml}$ and gaved for auberquent purlficat Lon. 
Bolution three times with 1 ml of n-heptane each tIme; the methyl eaterg of Krebs cycle Interwedfatea were thep extracted with to 10 w1 portions of chloroform; the chloroform extract wag waghed wth a $1 \mathrm{H} \mathrm{Ma}_{2} \mathrm{CO}_{3}$ aolution, followed by water until neutral, and then dried over enhydrous Na2 $\mathrm{SO}_{4}$. One hundred $\mu 1$ of Internal atandard, dImechyl-adlpate, was added and the chlorofotm extract was reduced to $10-50 \mu 1$; a corventent volume (1 $\mu 1$ ) was then tnjected fnto the columin of gab-11quid chronatograph for geparation and measurement.

d. Gas-Liquid Chromatography

A gas-11quid chroungtagraph equipped with a flame Ionization detector (Hewlett-Packard 7626A) was used tn thig atody. The colum (g1age, 1/8" 1.d. $x$ 6 ft) was packed with 100-120 mesh Gaschrom $P$ costed with $10 \mathrm{z}$ EgSG-X (App 11ed Sclence Loboratorles). Temperature progranting was from $100-210^{\circ} \mathrm{C}$ at $6^{\circ} \mathrm{C} / \mathrm{minute}$ and then matntained 1aothermally for 15 minutea; the carrier gas flow (Helium, ultra high purtty grade, Unton Carbide Corp.) was 41 m1/ minute.

Before a new coltum wag uaed, It was conditioned for two daye at $220^{\circ} \mathrm{C}$ and perlodically Infected with silyl-8 columim conditioner (Plerce chemical Co.).

\section{e. Quantitation}

Peak areas were calculated as peak hefght $x$ retention time. The volume vartationa of amples were corrected by adding $25 \mathrm{pg}$ of dimethyl-adipate as Internal atandard before concentratfng the gample. The detector regponge for dimethyl-adipate was linear up to $2 \mu g$. Retent Ion timas and peak areas were then compared wth those of both lndLvidul pure actds and their atandard mixtures whlch were methylated directly with BP3-methanol and axtracted 
into chloroform, The reconery from the extraction and purification procedureg was calculated and the tigaue concentration levelg were meabured (Table 4).

\section{Volat 1le Fatty AcLda (VPA) Determinat lon}

The analya1a for volatile fatty aclda fol loured that deacribed by GLbb et a1. $(1973)$.

\section{a. Deproteintzation of TIasue Honogenate}

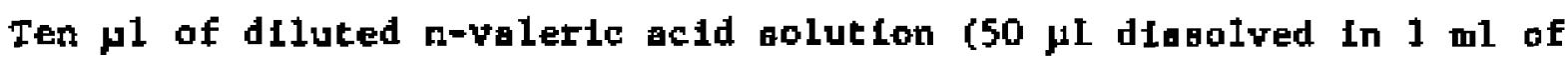
ethyl acetate) was added to $10 \mathrm{ml}$ of mugel timgue homogenate and 10 ml of glass diatilled water (blank control) as Internal standard (preliminary studles Indicated that the ribbed musel doeg not contaln a measurable amount of $n$-valertc acid). After one w1 of cold $70 \%$ perchlorio actd was added, the mixture was ahaken $v$ gorougly for obout 30 seconda, maintained cold for an additional 10 minutes to agare complete proteln prectpitation, and then centrifuged, This deproteinfzation procedure war repeated with 1 ml of cold $70 \%$ perchloric acid. Aftez the supernatant was neurralized whth a solution of $50 \%$ KOH untel cessatios of furthet cryatal formation, it was then matntalned in a refrIgerator overnight. The KC104 crystala which had formed were removed by centrifugation and the clear oupernatant was baved for further preparation.

\section{b. Purffication}

After deprotelnization, the sample was then eaturated with Macl, adu Juated to pH 11-12 wth 50\% $\mathrm{kOH}$, and centrifuged agala to temove any rema InIng $\operatorname{KolO}_{4}$ prectpitate; $10.0 \mathrm{ml}$ of ether wes then added and the tube capped, ahaken on a vortex agltator at high gped, and centrlfuged to promote aeparation; the ether phase was then removed and dincarded. The remalning aqueou. 
TABLE 4

RECOVERY OF A STANDARD MLTTURE OF KAEBS CTCLE IMTERYEDIATES (GXTRACTION AND PURTFICAT ION PROCEDIRE)

\begin{tabular}{|c|c|c|c|}
\hline Intermed late & $\begin{array}{l}\text { Standard } \\
\text { M1xture } \\
\text { (mi) }\end{array}$ & $\begin{array}{l}\text { Detector } \\
\text { Aenponge* }\end{array}$ & $\begin{array}{c}\text { B } \\
\text { Recovety of } \\
\text { Standard } \\
\text { Mixture }(\mathcal{H})\end{array}$ \\
\hline Fumarate & 5.0 & 105.0 & 6.9 \\
\hline Succinate & 5.0 & 135.9 & 87,1 \\
\hline Ad Ipate & 5.0 & 191.5 & $=$ \\
\hline Malate & 30.0 & 61.5 & 31.2 \\
\hline a-keto-Glutarate & 15.0 & 168,6 & 9.8 \\
\hline cts-Aconitate & 5.0 & 69.2 & 59.1 \\
\hline citrate & 20.0 & 113.3 & 56.3 \\
\hline
\end{tabular}

*Detector Regponge $=\frac{\text { peak helght } x \text { retention time }}{\text { hg actd }}$

A. Dry atandard acid mixture wa methylated with 77 BF $_{3}$ methanol and the methyl escere were extracted directly Into chloroform, A one $\mu 1$ aliquat from a total volume of 10 ml was infected Into the chromatographic columa.

B. Standard acid mLxture (Table 3) was taken through the extraction and purification procedure. The recovery (z) was oalculated by comparing the detector regpongea found with the data show in colum $A$. Internal otandard of methyl eatera of adlpate was ubed to correct for vartation in the final volume of the eample. 
phase was brought to pH 2-3 wtth $4 \mathrm{~N}$ HCl, ethyl acetate (10 m1) was added and the tube was vortexed for a fow minuteg and then centrifuged again. The acidlc aqueous phase was extracted twlce with 5 ml of ethyl acetate each tIme; the ethyl acetate fractiong were comblned and drted over antytrous god tum aulphate to remove traceg of water. The dried extract was then carefully coneentrated wth a alow atrean of dry nitrogen gas to approxtmately 50-100 $\mu 1$ for gas-11quid chromatogeaphic analyala.

c. Gas-Lequid Chromatography

A conventent allquot $(\sim 1 \mu 1)$ of concentrated VFA sample was then Injected fnto the gas-11quid chromatograph (Hewlett-Packard 7626A) equipped wth a flame tonlation detector. The colum ( 1 lag, $1 / B^{\prime \prime} 1 . d, x 6$ ft) was packed with 80-100 mesh Cbromodorb WAW coated with 107 sp 1200 supplemented with $1 \%$ phosphorlc acld (Supelco, Inc,). Temperature programnlng whs from $70-1400 \mathrm{C}$ at $4 \mathrm{O}^{\mathrm{C}} / \mathrm{minute}$ and the carrier gas flow (Helium, ultra high purity Brade, UnIon Garbide Corporation, New York, N.Y.) was $69 \mathrm{ml} / \mathrm{mInute.}$

Peak areas were integrated as peak hefght $x$ retention time and corrected for detector regponges. Detector responge factors were determfned Fror gag-11quid chromatograma obtained after infection of a atandard volat1le fatty actd mixture (Table 5). The mixture was prepared by diasolving 10 pl each of proptonic, teo-butyric, butyr lc, lao-valet le and valeric acta (SLgma Chemical Co, ) In 500 pl of IN acetic acLd.

$4.38 \mathrm{p}$ mole of n-valertc actd was added to the thaue homogenate aa Internal atandard at the atart of ample preparation and the fraction of n-valeric acid wa determined from the sample Injected; this ratio waa uged to comvert the amount of volatile fatty acid in the bample to that In murgel tiague, 
TABIE 5

DETECTOR RESFONSE FACTORS OF FRE VOLATILE ACIDS AS DETERMINED IN A STANDARD HIXTURE

\begin{tabular}{|c|c|}
\hline Volattle Fatty Actd & Detector Responge Factor \\
\hline Froptontc $\left(\mathrm{C}_{3}\right)$ & 3,952 \\
\hline 1ag-Butyric (160-C4) & 10,989 \\
\hline Butyr Le $\left(\mathrm{C}_{4}\right)$ & 11,905 \\
\hline ted-Valerte $\left(180-C_{5}\right)$ & 21,739 \\
\hline Waleric (C5) & 23,810 \\
\hline
\end{tabular}

*Detector Regponae Factor - peak height $x$ retention time 
Before t new cotumn could be used succesafully, 1t was atabilized by conditioning for 24 hours at $1500 \mathrm{C}$ and then by perlodicatly fnjectIng silyl8 coltmin condittoner (Plerce Chemical Co.) to reatore coltmin efflctency.

\section{Alanife, Lactate and Pyruvate Detetginations}

The日e procedures were modifled from kluytmans et al. (1975) and the SIgma Bulleting 726 uv and 826 uv (SIgna Chemical Co.). The honogenate (10 ml) wat deprotelnized by addition of $1 \mathrm{ml}$ cold 707 perchloric acid and ahaken vigorouly for approximately 30 aeconda. The mixture was kept cold for an additional 10 minutes to asure complete protein precipitation and then centrifuged for 10 mLnutes. This procedure was repeated with 1 ml of cald $70 \%$ perchlorlc actd; the supernatant wag nevtralized with $50 \%$ koH and gtored in the refrtgerator overnight. The $\mathrm{KClO}_{4}$ cryatals formed wete then removed by centrifugat Lon and the clems supetnatant was uged for the determLnationa of 1-alantne, 1-lactate and pyrusate,

\section{a. 1(+)-Alanine Determination}

The raptd alantne dehydragenase (EC 1.4.1.1) micromethod of gohutgens et al. (1977) was adopted for this deternination:

$$
\begin{aligned}
& \text { Alantne dehydrogenage } \\
& 1(+)-A \operatorname{lan} 1 \text { e }+\mathrm{NAD}^{+}+\mathrm{H}_{2} \mathrm{O}+\text { Pycurate }+\mathrm{NH}_{3}+\mathrm{NhDH}+\mathrm{H}^{+} \text {. } \\
& \text { (LoH A340) (H1gh A940) }
\end{aligned}
$$

Aliquota of $0.05 \mathrm{ml}$ mugel tiague preparation were pipetted Into acrew-capped tubes, labelled for reference and experiment, and then 0,05 m1 water and 1.0 ml etandard lncubat loa mixture were added, The atandard Incubation mixture was prepared by digsolving 0.5 g bydrazine oulfate into 25 ml of TrLF base (200 mH, Stgma Chentcal Ca.), the solution adjusted to pH 9.0 with $1 \mathrm{M}$ KOH and then diluted to $50 \mathrm{ml}$ wth diatilled water. $0.1 \mathrm{ml}$ 
HAD ${ }^{+}$golution was added to the experimental tube (10 mg $B=N A b^{+}$digaolved in $0.55 \mathrm{ml}$ standard Incubation mixture), wh11e $0.1 \mathrm{ml}$ of the standard incubation mixture wa added to the reference mixture. The 1nitial abarbance at 340 mas measured in the recording apectrophotometer (Cary Hodel 15) agatnet reference and the enzymLe reaction was garted by the addition of 10 pl of alantne dehydrogenaes (ADH) contalning 2,2 untta laolated from

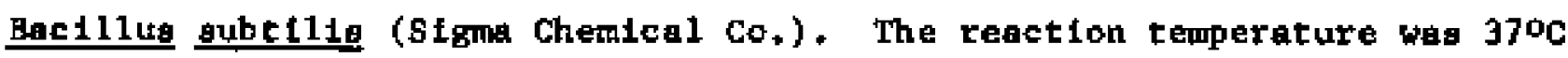
and the reaction $t$ ime wag 30 minutes. The gtandard curve ras prepared and the quantity of alanine In the aample was calculated from the increment of abaorbance and the btandard curve.

b. $1(+)$-Lactate Determination

1(+)-Lactate wag determfned us Ing lactate dehydrogenase (EC $1.3,99,1$ ) according to SIgma Bulletin 826 LW:

$$
\begin{aligned}
& \text { Lactate dehydrogenase } \\
& 1(+) \text {-Lactic Acld }+\mathrm{NAD}^{+}+\text {Pyruric Acld }+\mathrm{MADH}+\mathrm{H}^{+} \\
& \left(\operatorname{Low} \mathrm{A}_{340}\right) \\
& \left(\mathrm{HLgh}_{340}\right)
\end{aligned}
$$

$0.5 \mathrm{ml}$ of tiague preparation was diluted with $0.5 \mathrm{ml}$ of ditatled water and then $0.5 \mathrm{ml}$ atandard Incubation mixture war added. The atandard Incubation mixture was prepared by gently mLxing 2.0 ml glycine buffer (pH 9.2, contains glycthe and bydrazine) w1th 10 ag NAD ${ }^{+}$and $0.1 \mathrm{ml}$ lactic dehydrogenare. The reference solution was prepared by deleting $\mathrm{MAD}^{+}$; Lncubation was at $370^{\circ}$ for 50 minutes, and qeasured at $340 \mathrm{~mm}$ wth the recording spectrophotometer (Cary Hodel 15). The quantity of lactate was Interpreted from the standard curve.

c. Pyrurate Determination

Pyruvate was determined with lactate dehydrogenase (EC 1.3.99.1) according to sigma Bulletin 726 of uging the reverae reaction for the lactate aEsay: 
Lactate dehydrogenne

$$
\text { Pyrufic ACId + } \mathrm{AADH}+\mathrm{H}^{+} \rightarrow \mathrm{I}(+) \text {-Lactic AcId + } \mathrm{HAD}^{+} \text {. }
$$

$$
\text { (HLgh A340) (LOW } \mathrm{A}_{340} \text { ) }
$$

$0.5 \mathrm{~m} 1$ of Tritma ${ }^{R}$ base solution (tri-(hydroxymethy1)-aminomethane, 1.5 mal/1ter) was added to $2.0 \mathrm{ml}$ of tisaue preparation, mlxed by gentle 1nverslon, adjusted to $\mathrm{PH} 9$, and $0.5 \mathrm{ml}$ MADH solutton was added. The NADH solution was prepared by pipetting $2,2 \mathrm{ml}$ Trizma $^{R}$ base golution $1 \mathrm{nta} 1 \mathrm{mg}$ NADH. After two minutes, the abaorbance at 340 mo was meagured agalnst a reference solution using the Cary Mode1 15 recording spectrophotometer; the reference was prepered by deletfag NADH. The enzymlc reaction was atarted gubgequently by the addition of 0.05 ml of lactic dehydrogenase. After two to five minutes, the final abarbance at 340 nn war measured and the quanticy of pyrurate in the gample calculated from the 1nctement of absorbance at $340 \mathrm{rm}$ and the standard curve. 
RESULTS

Prel tminary Analyate of the Oyeter, Crageostren yirglatce

A preliminary abalyaig of adult oygters was undertaken prior to the more detafled etudy of the rtbbed mogel. In order to 1nvegtigate anaerobtc metabolfgm, varloug tiogue preparationg and procedures were tried. In contragt to the prevfoug reports on blvalve anaerob co metabolian whet employed enzymatic methods and analyzed only for succinate, a gas-11quid chromatographic method whoh analyzea aeven Krebo cycle intermediatea altaltaneougly was adopted for this study after modfflcetiong (de S11va, 1971).

Setiefactory extraction. purification and quantfication of wethyl agterg of Kreba cycle intermediateg from oyatere have been obtalned and ia ghown In Flgure 4 and Table 6. Single regolved peaks were observed for the dimethyl esterg of fumarate, succinate, malate and the trimethyl estera of cla-aconitate, cItrate and fao-citrate; two adjacent peaka qere obegred for trimethyl egtera of o-keto-slutarate. The not abundant 1ntermedite In the oyater clague was malate wheh wae followed by citrate, gucclnate and then fumarate, q-keto-glutarate; cla-aconitate and lab-citrate were prebent 1a trace amounta. The total concentration to oyater tiastie ranged from 752 to 4,092 nole $/ g$ wet we $t_{g} h t$. These regultg were reported $1 \mathrm{p}$ part (Ho and Zubkoff, 1978).

Detalled Study of the Rtbbed thogel, Goukeng tan demizin

Anelyals of the ribbed masels matntalned hypoxically for 51 houra at 150C revealed that auccinate, propionate and alanine accumulat in these 
FIGURE 4. GAS-LIQUID CHROHATOGRAFHY OF METHYL ESTERS OF KAEBS GYCLE TNTERYEDLATES OF OYSTER, CRASSOSTREA VIRGINICA.
(A) Standard Intermediate mixture
(B) Standard Intermediate mixture + oyster mantle tiogue
(C) Oyater mantle tisate
a = Funtarate
b = Succ Irate
c Adipate (Internal etandard)
d = Malate
e, $f=a$-keto-glutarate
$\mathrm{g}=$ cle-Aconitate
$h=$ citrate
1 = 1so-citrate




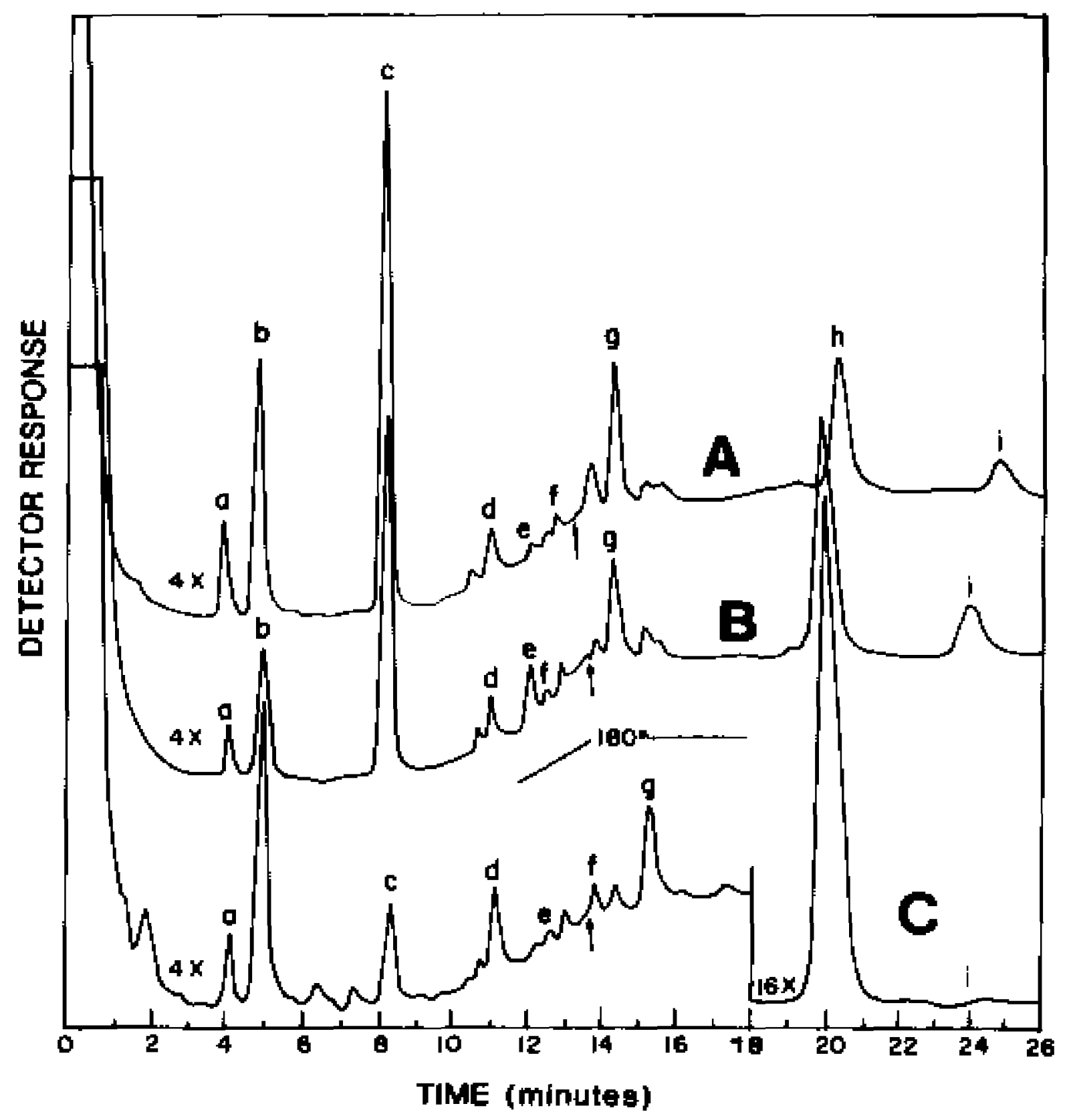




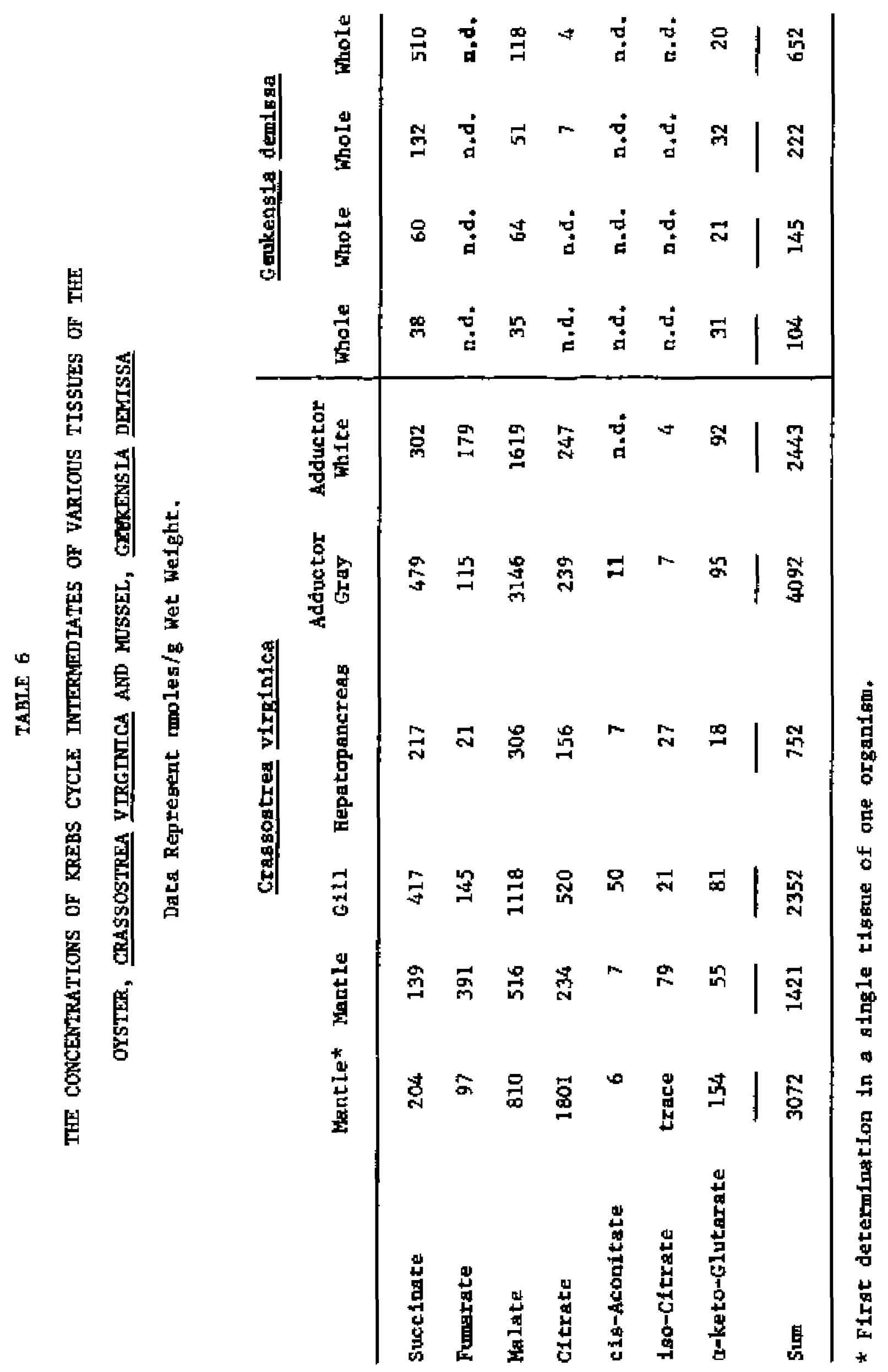


anImalo. The same experiment showed only smil changes which wete signif1cant In the quantetiea of the other thetabolites.

A gas-11quid chromatogtam of the Krebs cycle fatermediates obtalned from tfague extractg of control and experimental Gokengla demigan 1s der plcted in Figure 5. The same quantity of dimethyl adipate (peak c) was added an an Internal atandard to both control and exper iment extracts. It 16 clear that under hypoxic conditions, the aucolnate peak area (peak b) Increaged (Figure 5B and SC). Gas-1 lquid chromatograms of the volatile fatty aclda are shown in Figure 6. Proptonate (c3) is clearly demonatrated to accumulate hypoxically. Acetle actd (C2) is also detected but la deleted from further consideration becatue a similar peak with game retention time appeared fn blank controle.

Nimerteal data depteting and comparing concentrations of polysaccharides and key Intetmedistes in control and axpertinental musgels is pregented In Tables 7,8 , and $9 *$ It can be geen that succinate Increased about four-fold from $4,66 \mathrm{pmole} / \mathrm{g} \mathrm{dry}$ wetght th control animis to $19.63 \mathrm{pmole} / \mathrm{g}$ dry weight $t \pi$ mugela kept under $N 2$ for 51 hours at $150 \mathrm{C}$. There Ia a 1 a a conconitant amal1 increase In the level of malate (1.29 fmole/g dry weIght), but whether this Is olgnificant remains questlonable at this time * Concentrations of a-keto-glutarate, cig-aconitate and clcrate are fow and do not appear to change hypoxically.

The average proplonate concentration In the control group 1a 3.45 fmole/s dry weight, and 14.16 fmole/g dry weight In musela malntained hypoxica11y. This represents a four-fold tncreage. It la also evident that there ig virtually no change in 1so-butyrate, butyrate and Iaovalerate durtng 51 houre of hypoxia. 
FIGURE 5. GAS-LIQUTD CHROMATOGRAPHY OF METHYL ESTERS OF KREBS CYCLE INTEREDZATES OF MUSSEL, GETKENSIA DEMSSA.

(A) Standard Intermedtate mfxture

(B) Gexkensia demisea after malntaining 51 hours with aetated water

(C) Geukeng1a demisga after 51 houre of hypoxia
a = Fumarate
b = Suce Inate
$c$ = Adipate (Internal atandard)
$d$ = Halate
e, f = o-keto-clutarate
g c 1a-Acon 1tate
$h=$ citrate 


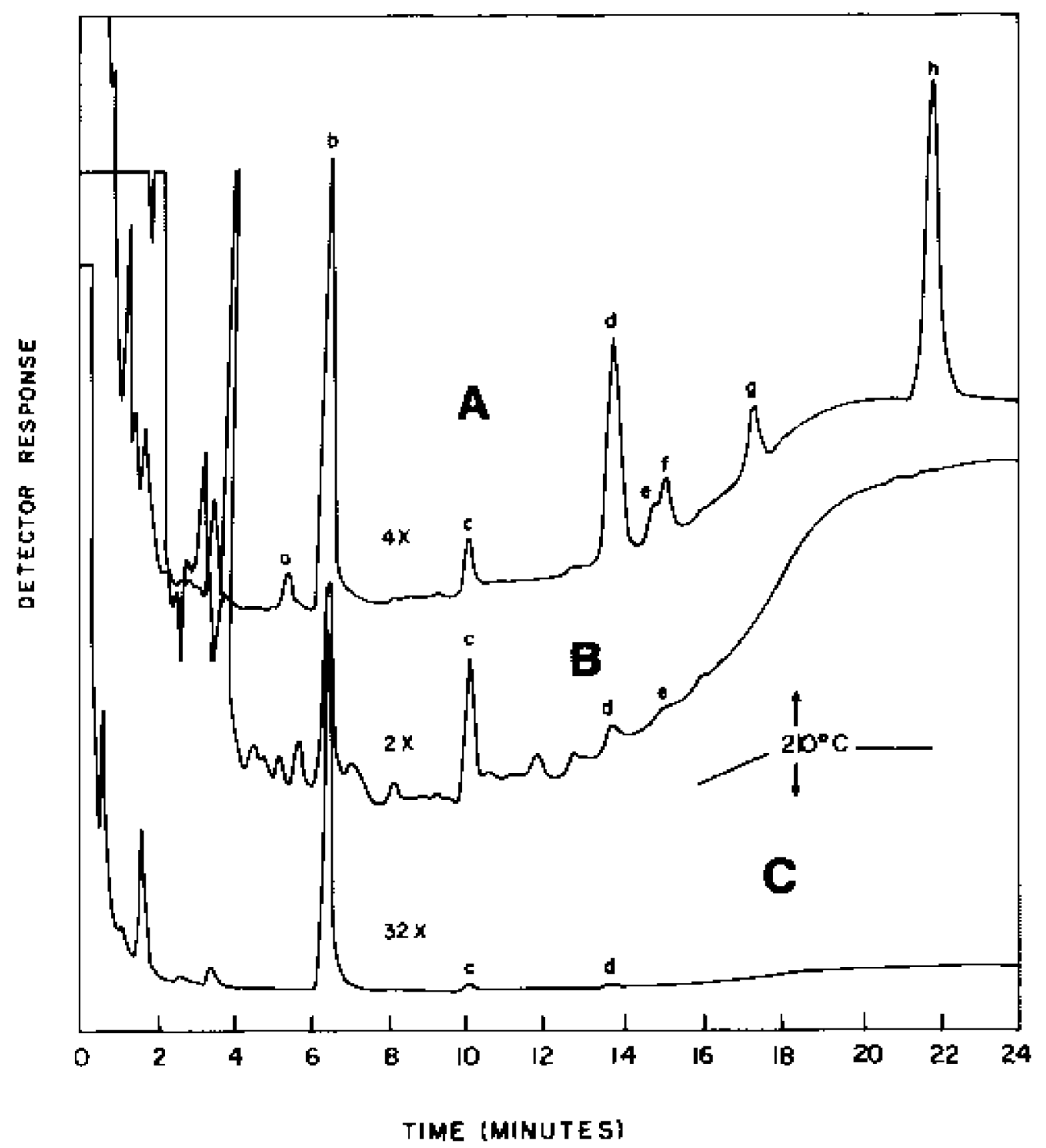


FIGURE 6. GAS-LIQTID CHROUATOGRAPHY OF VOLATILE FATTY ACIDS,

(A) Standard acid mixture

(B) Geukeng1a deqlasa after maLtaining 51 hours with aerated water

(C) Geukeng Le demlsen after 51 hours of hypoxia

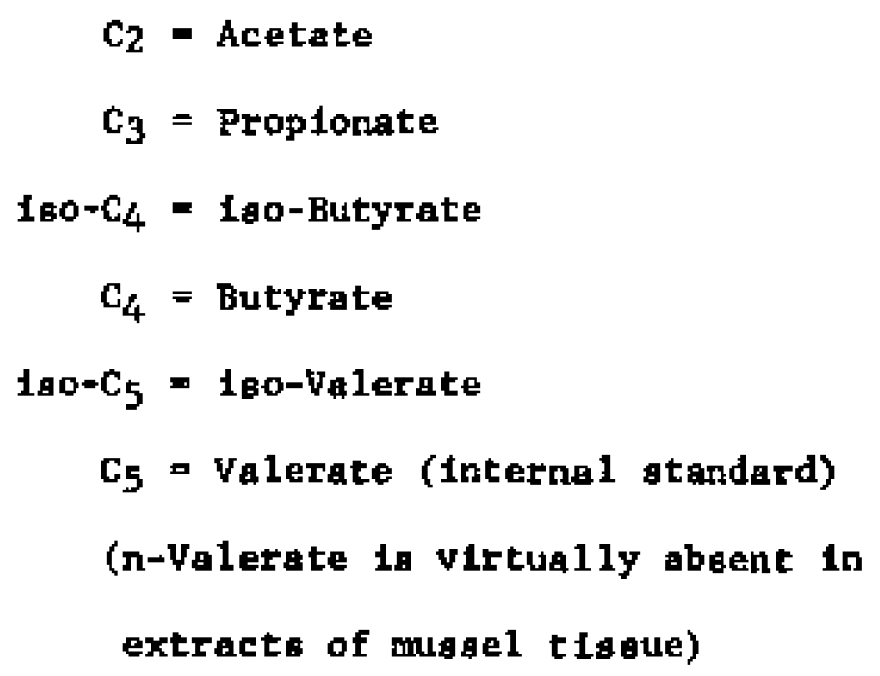




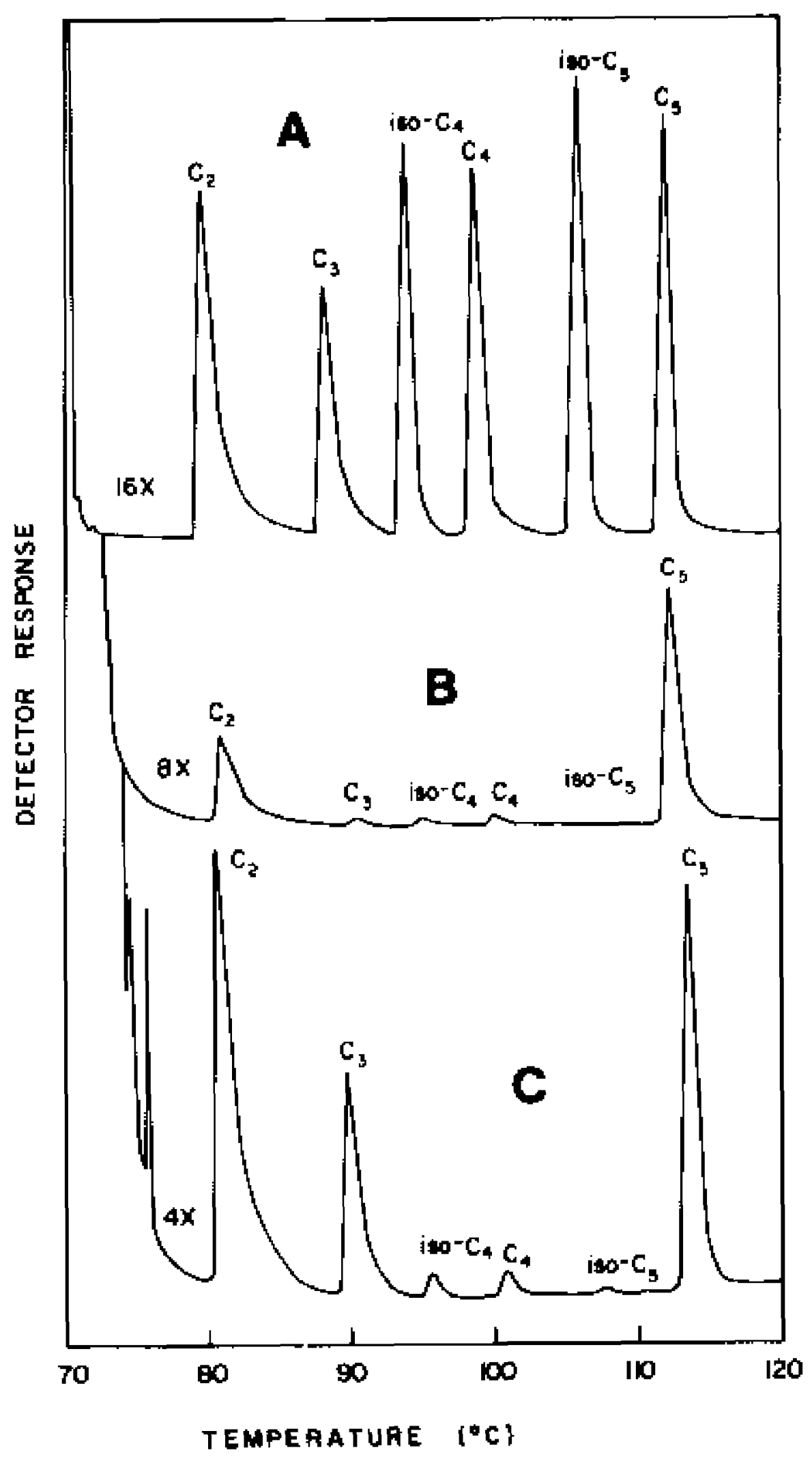


TABLE 7

CONCENTRATIONS OF POLYSACCHARIDE AKD KEY METABOLITES OF GELKENSIA DEMISSA AFTER MAINTAINIMG AT 15' C POR 51 HOURS WTTH AERATED RIVER WATER (DECEMEER 1978)

Hosela

$1 \quad 2 \quad 3 \quad 4 \quad(\bar{n}=4)$

A. Hubala (polygacchartde in mo/g dry wefght)

$\begin{array}{lrrrrr}\text { Slze (cm) } & 12.00 & 11.00 & 10.50 & 11.50 & 11.25 \pm 0.65 \\ \text { Dry we Lbht (s) } & 2.86 & 4.15 & 2.14 & 2.27 & 2.86 \pm 0.92 \\ \text { Polygaccher } & 86.00 & 267.20 & 128.70 & 185.20 & 166.78 \pm 78.31\end{array}$

B. Hetabolitea (pmole/g dry welght)

\begin{tabular}{|c|c|c|c|c|c|c|c|}
\hline $\begin{array}{l}\text { Succinate } \\
\text { Halete } \\
\text { d-keto-Glutarate } \\
\text { cig-Aconitate } \\
\text { Cltrate } \\
\text { Ptoplonate } \\
\text { loo-Butyrata } \\
\text { Butyrate } \\
\text { lao-Valerate } \\
\text { Alantne } \\
\text { Lactate } \\
\text { Pyrnate }\end{array}$ & $\begin{array}{r}0.84 \\
0.77 \\
0.67 \\
* 0.0 . \\
0.4 . \\
2.19 \\
0.89 \\
0.96 \\
0.12 \\
57.58 \\
5.01 \\
0.25\end{array}$ & $\begin{array}{r}0.78 \\
0.84 \\
0.25 \\
\text { n.d. } \\
0 . d \\
1.50 \\
0.74 \\
0.72 \\
0.09 \\
60.73 \\
3.94 \\
0.35\end{array}$ & $\begin{array}{r}2.66 \\
1.03 \\
0.65 \\
n .0 . \\
0.15 \\
4.73 \\
1.75 \\
1.31 \\
0.20 \\
76.78 \\
6.05 \\
0.48\end{array}$ & $\begin{array}{r}14.35 \\
3.31 \\
0.55 \\
0.4 . \\
0.11 \\
5.38 \\
1.28 \\
1.29 \\
0.20 \\
65.66 \\
- \\
0.43\end{array}$ & $\begin{array}{r}3.45 \\
1.17 \\
1.07 \\
0.15 \\
65.19 \\
5.00 \\
0.38\end{array}$ & 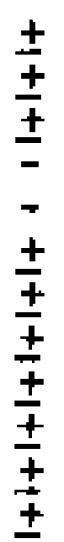 & $\begin{array}{l}1.89 \\
0.28 \\
0.28 \\
0.06 \\
8.41 \\
1.05 \\
0.10\end{array}$ \\
\hline
\end{tabular}

C. Sum of metaboliteg (pmole/g dry wetght)
69.28
69.97
95.79
92,56
83.10

D. Sum of succinate, proplonate and alanine (fmole/g dry welght)
60.61
63.01
B4.17
85.39
73.30

*n.d. - not detectable 
TABLE $\mathrm{g}$

GONCENTRATIONS OF POLYSACCHARIDE AND KEY METABOLITES OF

GETKENSIA DEMISSA AFTER 51 HOURS OF HYPOXLA (DECEMBER 1978)

Hursedg

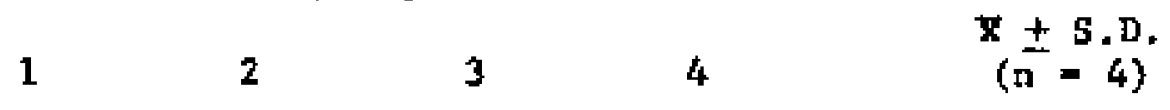

A. Mugels (polyagccharide In mg/g dry weight)

\begin{tabular}{|c|c|c|c|c|c|}
\hline $\begin{array}{l}\text { SLze (cm) } \\
\text { Dry welght (g) } \\
\text { Polygacchar lde }\end{array}$ & $\begin{array}{r}11.00 \\
2.22 \\
58.10\end{array}$ & $\begin{array}{r}11.50 \\
2.95 \\
124.40\end{array}$ & $\begin{array}{r}11.00 \\
2.19 \\
54.20\end{array}$ & $\begin{array}{r}11.00 \\
2.71 \\
101.30\end{array}$ & $\begin{array}{r}11.13 \pm 0.25 \\
2.52 \pm 0.37 \\
84.50 \pm 34.10\end{array}$ \\
\hline
\end{tabular}

B. Metaboliteg (pmole/g dry weight)

\begin{tabular}{|c|c|c|c|c|c|c|}
\hline $\begin{array}{l}\text { Succlnate } \\
\text { Kalate } \\
\text { q-keto-Glutarate } \\
\text { cla-Aconftate } \\
\text { Gitrate } \\
\text { Prop lonate } \\
\text { Ioo-Butyrate } \\
\text { Butyrate } \\
\text { loo-Valerate } \\
\text { Alanfne } \\
\text { Lactate } \\
\text { Py ruvate }\end{array}$ & $\begin{array}{r}9.60 \\
2.45 \\
0.35 \\
0.39 \\
0.20 \\
15.56 \\
1.18 \\
1.10 \\
0.19 \\
61.85 \\
9.37 \\
1.05\end{array}$ & $\begin{array}{r}8.86 \\
2.48 \\
0.23 \\
* \pi .0 \\
0.10 \\
16.79 \\
0.69 \\
0.80 \\
0.11 \\
79.47 \\
4.69 \\
0.37\end{array}$ & $\begin{array}{r}36.23 \\
4.43 \\
0.14 \\
n .4 . \\
0.11 \\
4.77 \\
1.14 \\
1.26 \\
0.22 \\
71.39 \\
7.30 \\
0.57\end{array}$ & $\begin{array}{r}23.81 \\
1.76 \\
0.80 \\
0 . \mathrm{d} . \\
0.18 \\
19.52 \\
1.71 \\
1.16 \\
0.24 \\
71.61 \\
5.43 \\
0.30\end{array}$ & $\begin{array}{r}19.63 \\
2.78 \\
0.38 \\
0.15 \\
14.16 \\
1.18 \\
1.08 \\
0.19 \\
71.08 \\
6.43 \\
0.57\end{array}$ & $\begin{array}{ll} \pm & 13.03 \\
\pm & 1.15 \\
\pm & 0.29 \\
\pm & \\
\pm & 0.05 \\
\pm & 6.48 \\
\pm & 0.42 \\
\pm & 0.20 \\
\pm & 0.06 \\
\pm & 7.21 \\
\pm & 1.71 \\
\pm & 0.34\end{array}$ \\
\hline
\end{tabular}

c. Sum of metabalites (mole/g dry welght)
102.29
114.53
127.56
126.52
117.63

D. Sum of succinate, proplonate and alanine (jonole/g dry weight)

$\begin{array}{lllll}87.01 & 105.12 & 112.39 & 114.94 & 104.87\end{array}$

*n,d, = not detectable 
TABLE 9

CONCENTRATIONS OF POLYSACCEAR IDE AND KEY METABOLITES OF GEITRESLA DEMESA AFTER MAINTAINING UNDER OXYGEN AND NITROGEN

AT 150C FOR 51 HOURS (DECEMBER 1978)

Exposed to $\mathrm{O}_{2}$ Expored to $\mathrm{H}_{2}$

$\begin{array}{cccc}\bar{x} \pm S . D . & \bar{x} \pm s . D . & \text { Difference } & \text { Accumulation } \\ (\bar{n}=4) & (\bar{n}=4) & \left(\bar{x}_{\mathrm{H}_{2}}-\overline{\mathrm{X}}_{0_{2}}\right) & \left(\gamma_{1}\right)\end{array}$

A. Hugaels (polysaccharide fn mg/g dry welght)

Size (ctr)

Dry weight (g)

Foly saccharide

$11.25 \pm 0.65$
$2.86 \pm 0.92$
$166.78 \pm 78.31$

$11.13 \pm 0.25$

$2.52 \mp 0.37$

$84.50 \mp 34.10$
$\left(\bar{x}_{\mathrm{H}_{2}}-\overline{\mathbf{x}}_{\mathrm{O}_{2}}\right)$
(1)

B. Hetebolite日 (pmole/g dry weight)

\begin{tabular}{|c|c|c|c|c|c|c|}
\hline $\begin{array}{l}\text { Succinate } \\
\text { Malate } \\
\text { a-keto-Glutatate } \\
\text { Proplonate } \\
\text { lac-Butyrate } \\
\text { Butyrate } \\
\text { leo-Valerate } \\
\text { Alanine } \\
\text { Lactate } \\
\text { Pyruvate }\end{array}$ & $\begin{array}{l}4.66 \pm \\
1.49 \pm \\
0.54 \pm \\
3.45 \pm \\
1.17 \pm \\
1.07 \pm \\
0.15 \pm \\
65.19 \pm \\
5.00 \pm \\
0.38 \pm\end{array}$ & $\begin{array}{l}6.52 \\
1.22 \\
0.18 \\
1.89 \\
0.28 \\
0.28 \\
0.06 \\
0.41 \\
1.05 \\
0.10\end{array}$ & $\begin{array}{r}19.63 \pm \\
2.78 \pm \\
0.39 \pm \\
14.16 \pm \\
1.18 \pm \\
1.08 \pm \\
0.19 \pm \\
71.08 \pm \\
6.43 \pm \\
0.57 \pm\end{array}$ & $\begin{array}{l}13.03 \\
1.15 \\
0.29 \\
6.48 \\
0.42 \\
0.20 \\
0.06 \\
7.21 \\
1.71 \\
0.34\end{array}$ & $\begin{array}{r}14.97 \\
1.29 \\
-0.16 \\
10.71 \\
0.01 \\
0.01 \\
0.04 \\
5.89 \\
1.43 \\
0.19\end{array}$ & $\begin{array}{r}43.34 \\
3.73 \\
- \\
31.00 \\
0.03 \\
0.03 \\
0.12 \\
17.05 \\
4.14 \\
0.55\end{array}$ \\
\hline
\end{tabular}

c. Sum of Metabolites (pole/g dry wefght)
63. 10
117.48
34.54
99.99

D. Sum of gucclate, proplonate and alanine (jmole/g dry veight)
73.30
104.87
31.57
91.40 
Under hypoxic condftiong, alantme levels Increaged from 65.19 to 71,08 pmole/g dry weight. Together, alentne, eucctnate and proplonate account for $91.40 \%$ of the accumulation of metabol1tes (Table 9). There are only small changes of lactate and pyruvate concentrationg from 5.00 to 6.43 and from 0.38 to 0.57 fmole/g dry welght, respectively.

Because of the wide range of valies measurd, the amounts of polyancchartde do not provtde a clear Indfcatfon for changea due to hypoxia (Table日 7 and b). However, they Indfcate an Increased rate of polysaccharlde consutuption under the hypoxtc condition becaves the average concentrations dropped from 166.78 to $94.50 \mathrm{mg} / \mathrm{g}$ dry weight (Table 9).

The average values and atandard deviation durlng the time course atudy ( -2 to 4 days) are pregented In Tables 10 to 15 and summerized In Tables 16 and 17 and Figure 7 , The size, dry weight of each magel, and concentratlons of polysaccharides and some metabolites are ahown in theae tables. These mustis were etther asayed immediately after fteld collect lon (Tab1e 10), after two days actlimat Lon at $15^{\circ} \mathrm{C}$ with aerated water (Table 11), or after one to four days of hypoxta (Tablea 12-15). The average values of the concentrationg of key metabolitea (euccinate, propi= onate and alanine) after four days of hypoxia are compared and aumarized In Table 17 and plotted In Figure 7.

There 1s little of no change in concentration of any of the three mafor metabolites during the two days of aeclimation at $15^{\circ} \mathrm{C}$. However, eucclnate Incteaged from 0.95 to 3.47 mole/g dry weight after the firet two daya of hypoxia and then leveled off. The concentration of propionate did not change during the firat day of hypoxla 2.65 to $2.33 \mathrm{pmole} / \mathrm{g}$ dry welght). However, proptonate did increage altghtly to 7.02 fmole/g dry 


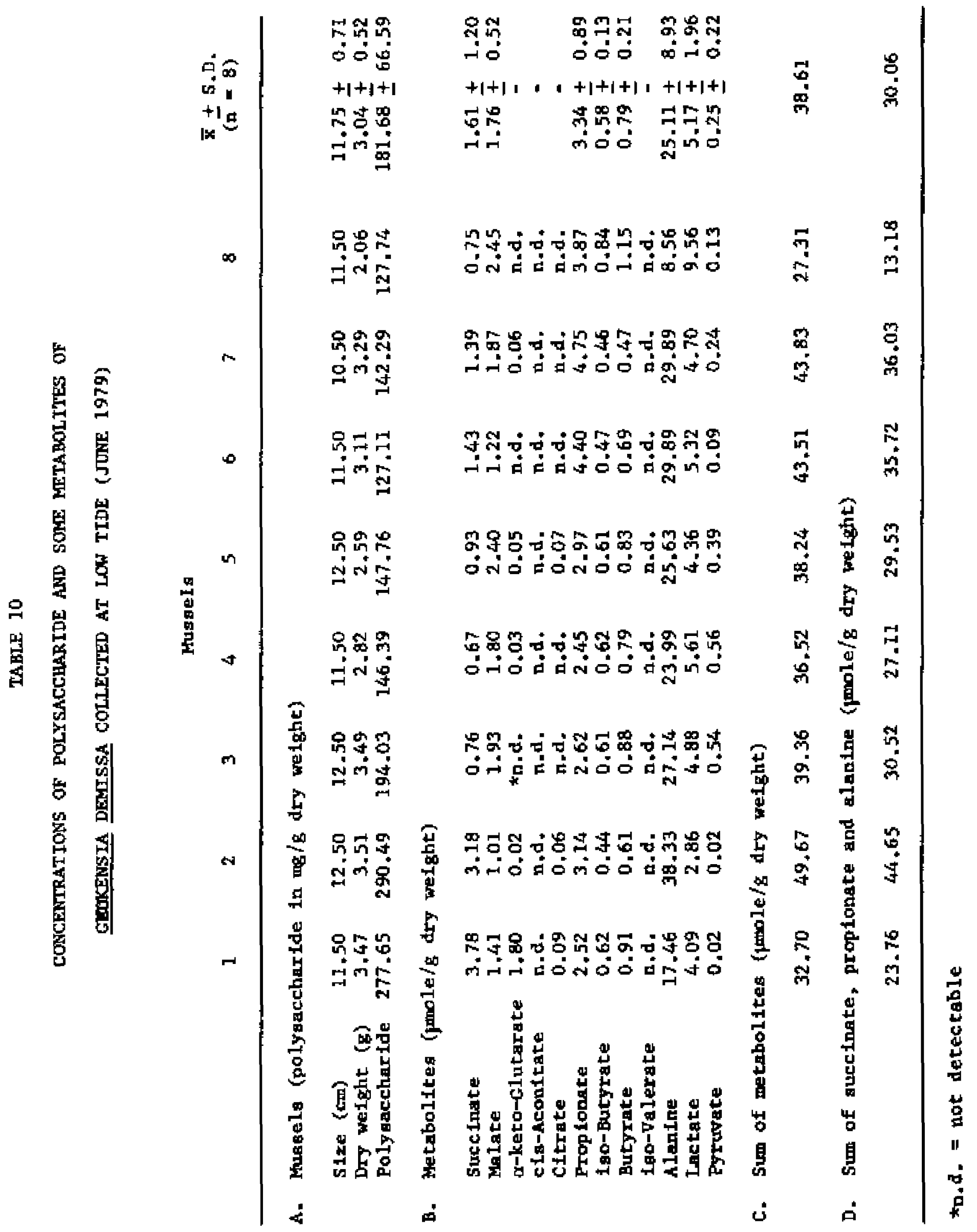


TABLE 11

CONCENTTATIONS OF POLYSACCHARTDE AND SOHE METABOLITES OF

GHOKENSLA DEMISSA AFTER THO DAYS ACCLIYATION AT

150C WTTH AERATED RIVER WATER (JUNE 1979)

Mugsels

$1 \quad 2 \quad 3 \quad \begin{gathered}x \pm 5 . D \\ (5-3)\end{gathered}$

A. Hugela (polyaaccharide in mg/g ory weight)

$\begin{array}{lrrrr}\text { S1ze (cm) } & 12.00 & 11.50 & 12.00 & 11.63 \pm 0.29 \\ \text { Dry welght (g) } & 3.70 & 3.58 & 1.40 & 2.89 \pm 1.29 \\ \text { Polyeacchertde } & 63.63 & 190.16 & 37.03 & 96.94 \pm 81.82\end{array}$

B. Metabolitea ( $\mathrm{mole} / \mathrm{g}$ dry welght)

\begin{tabular}{|c|c|c|c|c|c|}
\hline $\begin{array}{l}\text { Succinate } \\
\text { Malate } \\
\text { d-keto-Glutarate } \\
\text { cla-Acobitate } \\
\text { Cltrate } \\
\text { Proptonate } \\
\text { Iso-Butyrate } \\
\text { Butyrate } \\
\text { 1sa-Welerate } \\
\text { Alanine } \\
\text { Lectate } \\
\text { Pyrovate }\end{array}$ & $\begin{array}{r}0.77 \\
2.41 \\
0.04 \\
+n . d . \\
0.14 \\
3.36 \\
0.56 \\
0.77 \\
7 . d . \\
35.39 \\
5.93 \\
0.01\end{array}$ & $\begin{array}{r}0.50 \\
1.62 \\
0.25 \\
\text { n.d. } \\
0.16 \\
1.93 \\
0.46 \\
0.46 \\
n .0 . \\
32.04 \\
3.74 \\
0.62\end{array}$ & $\begin{array}{c}1.59 \\
1.35 \\
0.57 \\
\text { n.d. } \\
\text { n.d. } \\
= \\
- \\
= \\
13.20 \\
10.67 \\
0.24\end{array}$ & $\begin{array}{r}2.65 \pm \\
0.52 \pm \\
0.62 \pm \\
26.88 \pm \\
6.78 \pm \\
0.29 \pm\end{array}$ & 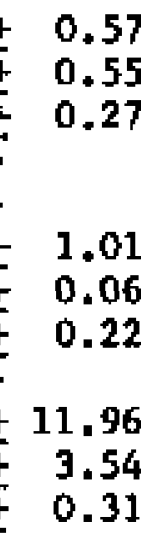 \\
\hline
\end{tabular}

C. Sum of metaboltteg (pmole/g dry wetght)

$$
49.38 \quad 41.80 \quad-\cdots+\cdots
$$

D. Sum of succinate, proplonate and alantne (jole/g dry wetght)

$$
\begin{array}{llll}
39.52 & 34.47 & - & 30.48
\end{array}
$$

$* n, d$. = not detectable 
TABLE 12

COHCENTRATIONS OF POLYSACCHARIDE AND KEY METABOLITES OF

GEUKBNSIA DEMISSA AFTER OWE DAY OF INPOXLA (JDNE 1979)

Musget

$1 \quad 2 \quad 3 \quad \begin{gathered}\mathrm{R} \pm \mathrm{s.D} . \\ (\mathrm{n}=3)\end{gathered}$

A. Musgelg (polygaccharide in mg/g dry welght)

$\begin{array}{lrrrr}\text { S1ze (cm) } & 11.00 & 11.50 & 11.50 & 11.33 \pm 0.29 \\ \text { Dry we1ght (g) } & 3.56 & 3.20 & 4.03 & 3.60 \pm 0.42 \\ \text { Polyaccharide } & 149.18 & 133.09 & 159.48 & 147.25 \pm 13.30\end{array}$

B. Netabolites (fmole/g dry weight)

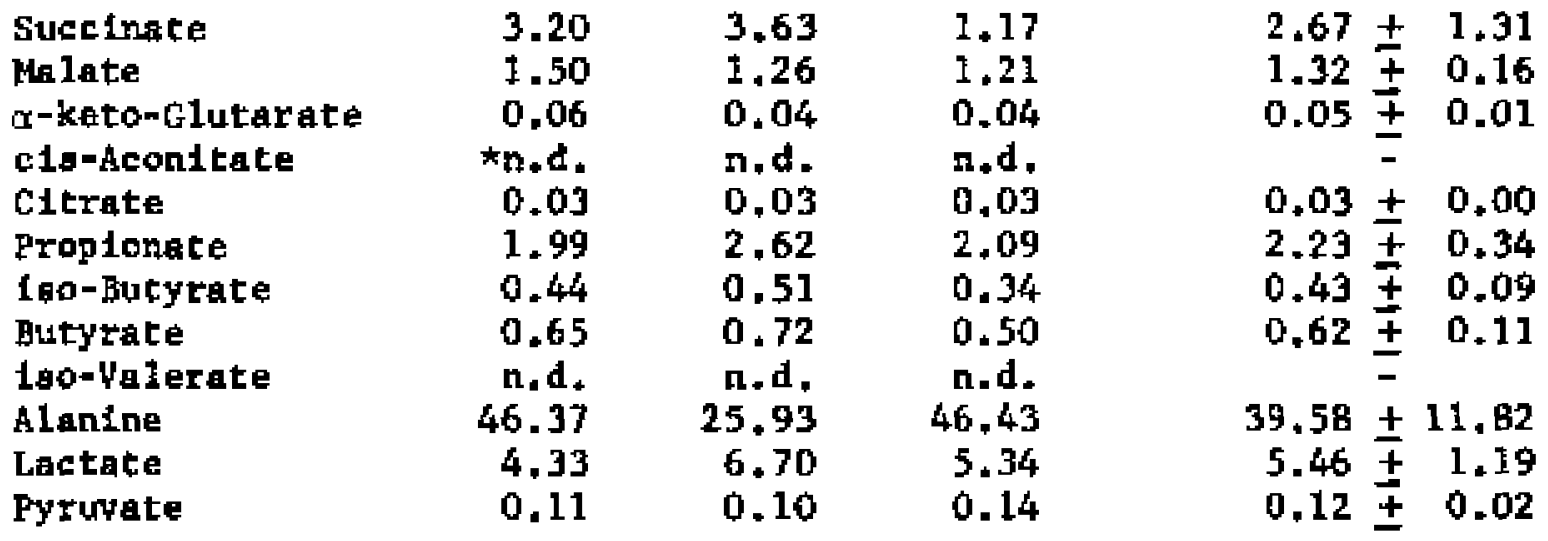

c. Sum of metabolites (fmole/g dry wefght)
58.68
41.54
57.29
52.51

D. Sum of Euccinate, proplonate and alanine (prole/g dry welght)
51.56
32.18
49.69
44.48

†.A. \#ot detectable 
TABLE 13

CONCENTHATIONS OF POLYSACCHARIDE AKD KEY METABOLITES OF GLUKNSIA DEMISSA AFTER TWO DAYS OF EYPOKLA (JUNE 1979)

Mugelo

$1 \quad 2 \quad 3 \quad \begin{gathered}\bar{x} \pm S+D . \\ (n-3)\end{gathered}$

A. Husaels (polygaccheride in go/g dry weight)

$\begin{array}{lrrrr}\text { SIze (cn) } & 10.50 & 12.50 & 12.00 & 11.67 \pm 1.04 \\ \text { Dry welght (g) } & 3.36 & 3.29 & 3.28 & 3.31 \pm 0.04 \\ \text { Polygacchartde } & 166.10 & 134.12 & 157.72 & 152.65 \pm 16.58\end{array}$

B. Metabolites (mole/g dry weight)

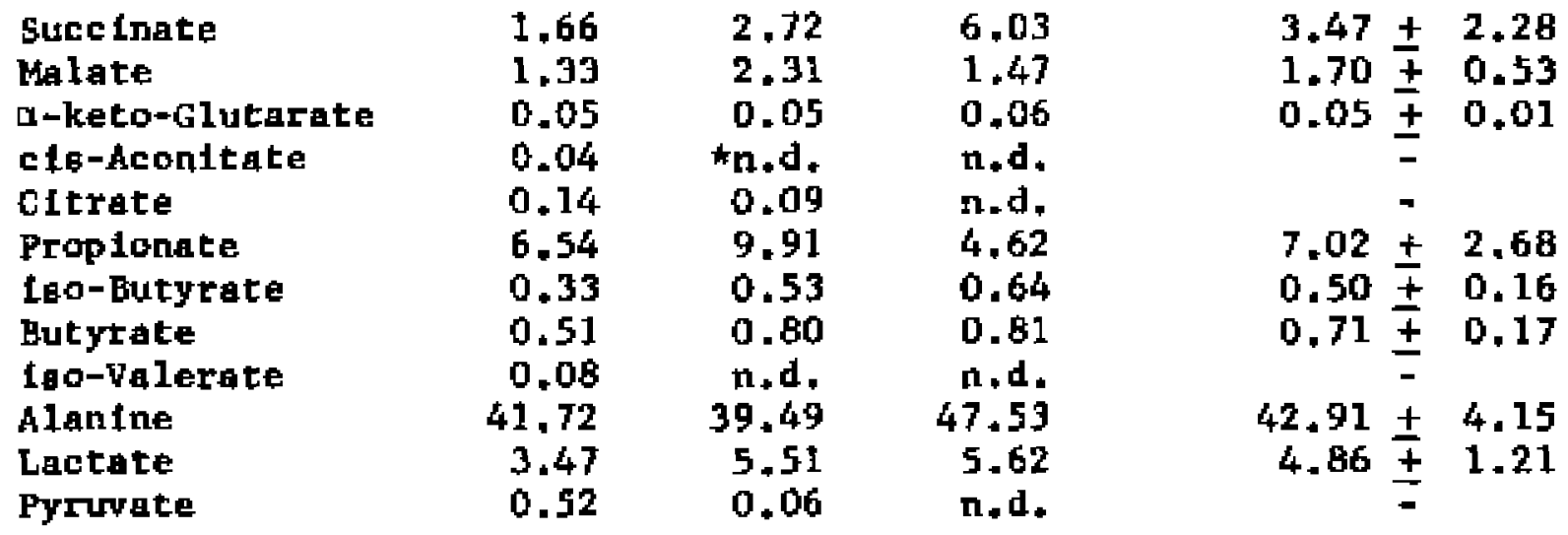

C. Sum of metabolites (mole/g dry welght)
56.39
61.47
66.78
61.22

D. Sum of eluctinate, proplonate and alanine (jmole/g dry weight)

$\begin{array}{llll}49.92 & 52.12 & 58.18 & 53.40\end{array}$

tn.d. = not detectable 
TABLE 14

CONCENTRATIONS OF POLYSACCHARIDE AND KEY METABOLITES OF G.TKENSLA DEMISSA AFTER THREE DAYS OF HYPOXIA (JUNE 1979)

Hug Bels

$1 \quad 2 \quad 3 \quad(\underline{\mathrm{n}} \pm 3, \mathrm{~S})$

A. Hugela (polygaccharide in mg/g dry weight)

$\begin{array}{lrrrr}\text { \$1ze (cm) } & 11.50 & 11.50 & 12.00 & 11.67 \pm 0.29 \\ \text { Dry we } 1 \text { ght }(g) & 2.50 & 3.84 & 3.60 & 3.31 \pm 0.71 \\ \text { Polysaceharide } & 36.70 & 267.72 & 207.11 & 187.18 \pm 92.14\end{array}$

B. Metabolites (pmole/g dry weight)

\begin{tabular}{|c|c|c|c|c|c|}
\hline $\begin{array}{l}\text { Succinate } \\
\text { Malate } \\
\text { r-keto-Glutarate } \\
\text { cia-Aconltate } \\
\text { Cltrate } \\
\text { Prop lonate } \\
\text { lao-Butyrate } \\
\text { Butyrate } \\
\text { Iso-Valerate } \\
\text { AlanLne } \\
\text { Lactate } \\
\text { Pyruvate }\end{array}$ & $\begin{array}{r}3.51 \\
1.69 \\
0.04 \\
* \pi . d . \\
0.11 \\
22.35 \\
0.73 \\
1.10 \\
\mathrm{n.d} \\
53.52 \\
7.95 \\
0.42\end{array}$ & $\begin{array}{r}2.13 \\
0.08 \\
0.01 \\
0.0 . \\
0.01 \\
20.69 \\
0.57 \\
0.74 \\
0.4 . \\
53.65 \\
5.27 \\
0.11\end{array}$ & $\begin{array}{c}- \\
= \\
- \\
- \\
16.44 \\
0.52 \\
0.71 \\
7.0 . \\
34.95 \\
5.56 \\
0.04\end{array}$ & $\begin{array}{r}2.82 \pm \\
1.28 \pm \\
0.03 \pm \\
0.06 \pm \\
19.83 \pm \\
0.61 \pm \\
0.85 \pm \\
47.37 \pm \\
6.26 \pm \\
0.19 \pm\end{array}$ & $\begin{array}{r}0.98 \\
0.57 \\
0.02 \\
0.07 \\
3.05 \\
0.11 \\
0.22 \\
\\
10.76 \\
1.47 \\
0.20\end{array}$ \\
\hline
\end{tabular}

c. Sum of metaboliteg (pmole/g dry weight)

$$
91.42 \quad 84.06
$$$$
79.30
$$

D. Sum of gluccinate, proplonate and alanine (jmole/g dry weight)

$$
\begin{array}{llll}
79.38 & 76.47 & - & 70.02
\end{array}
$$

\#n.d. = not detectable 
TABLE I5

CONCENTRATIONS OF POLYSACCHARIDE AND KEY METABOLITES OF

GEOKENSIA DEMISSA AFTER FOUR DAYS OF FYPOX IA (JUNE 1979)

Musa gela

$1 \quad 2 \quad 3 \quad \begin{array}{r}x \pm 5 . D . \\ (n+3)\end{array}$

A * Woels (polyaacchartde in mig dry wetght)

$\begin{array}{lrrrr}\text { Stze (cm) } & 12.00 & 11.50 & 11.50 & 11.67 \pm 0.29 \\ \text { Dry wefght (g) } & 4.19 & 3.09 & 2.80 & 3.36 \pm 0.73 \\ \text { Polysacchar dde } & 123.03 & 84.98 & 126.31 & 111.44 \pm 22.97\end{array}$

B. Metabol tea (jumole/g dry welght)

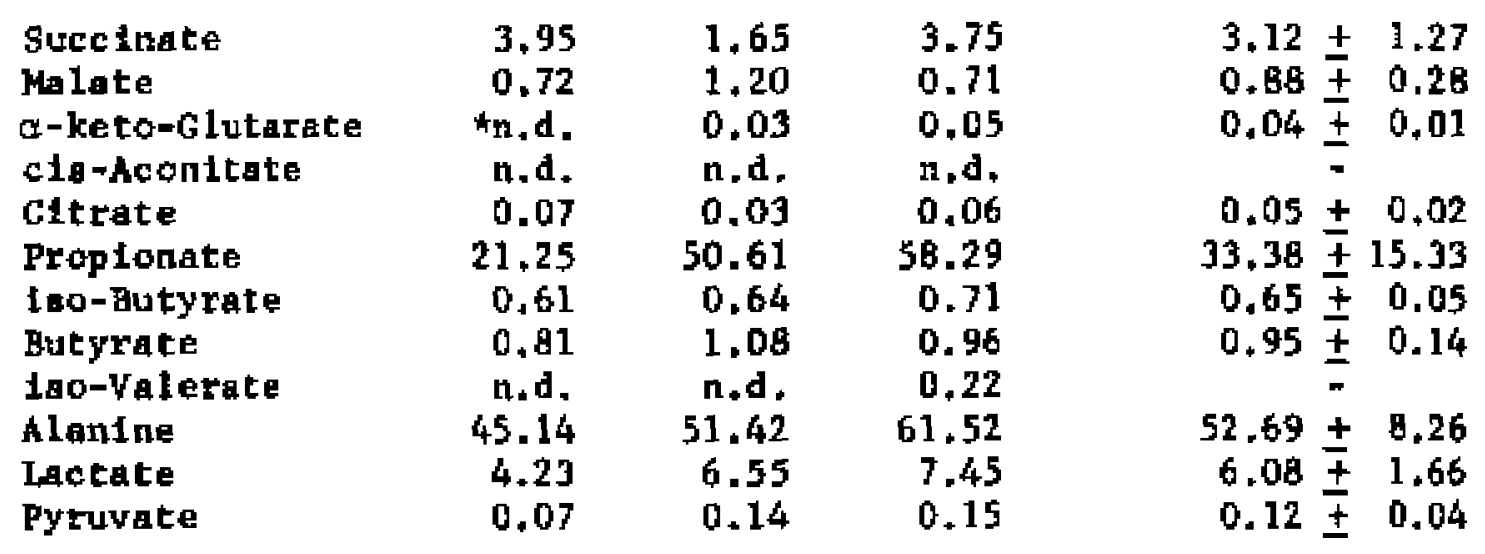

C. Sum of metaboltes (pmole/g dry weight)
76.85
113.35
103.87
97.96

D. Sum of aucclate, proplonate and alanine (gmole/g dry weight)
70.34
103.68
93.56
89.19

*n.d. = not detectable 
TABIE 16

AVERAGE CONCHTTRATIONS OF POLYSACCHARIDE AND KEY METABOLITES

OF G.UKEASLA DEMISSA AFTER FIELD COLLECT1OM (-2 DAYS),

TWO DAYS ACCLIMATIOH (O DAY) AWD OWE TO FOUR DAYS OF HYPOXIA

Deya of Hyoxia

$\begin{array}{llllll}-2 & 0 & 1 & 2 & 3 & 4\end{array}$

A. Muage1 (polysaccharide in mg/g dry welght)

$\begin{array}{lrrrrrr}\text { S1ze (cm) } & 11.75 & 11.83 & 11.33 & 11.67 & 11.67 & 11.67 \\ \text { Dry welght (g) } & 3.04 & 2.89 & 3.60 & 3.31 & 3.31 & 3.36 \\ \text { Poly gacchar 1de } & 181.68 & 96.94 & 147.25 & 152.65 & 187.18 & 111.44\end{array}$

B. Hetabolite (phole/g dry wetght)

\begin{tabular}{|c|c|c|c|c|c|c|}
\hline $\begin{array}{l}\text { Succ1nate } \\
\text { Malate } \\
\text { a-keto-Glutarate } \\
\text { Prop Lonate } \\
\text { Iao-Butyrate } \\
\text { Butyrate } \\
\text { AlanLne } \\
\text { Lactate } \\
\text { Pyruvate }\end{array}$ & $\begin{array}{r}1.61 \\
1.76 \\
- \\
3.34 \\
0.58 \\
0.79 \\
25.11 \\
5.17 \\
0.25\end{array}$ & $\begin{array}{r}0.95 \\
1.79 \\
0.29 \\
2.65 \\
0.52 \\
0.62 \\
26.88 \\
6.78 \\
0.29\end{array}$ & $\begin{array}{r}2.67 \\
1.32 \\
0.05 \\
2.23 \\
0.43 \\
0.62 \\
39.59 \\
5.46 \\
0.12\end{array}$ & $\begin{array}{r}3.47 \\
1.70 \\
0.05 \\
7.02 \\
0.50 \\
0.71 \\
42.91 \\
4.86 \\
0.29\end{array}$ & $\begin{array}{r}2.82 \\
1.28 \\
0.03 \\
19.83 \\
0.61 \\
0.85 \\
47.37 \\
6.26 \\
0.19\end{array}$ & $\begin{array}{r}3.12 \\
0.80 \\
0.04 \\
33.38 \\
0.65 \\
0.95 \\
52.69 \\
6.08 \\
0.12\end{array}$ \\
\hline
\end{tabular}

C. Sum of metaboliteg (prole/g dry welght)

$$
\begin{array}{llllll}
38.89 & 40.77 & 52.48 & 61.51 & 79.24 & 97.91
\end{array}
$$

D. Sum of auccinate, proplonate and alenine (mole/g dry weight)

$\begin{array}{llllll}30.06 & 30.48 & 44.48 & 53.40 & 70.02 & 89.19\end{array}$


TABLE I7

AVERAGE CONCENTRATIONS OF SUCCIMATE, PROPIONATE AND ALANILE OF MUSSELS, GADKENSLA DEMISSA AFTER FIELD COLLECTION (-2 DAYS), TWO DAYS OF ACCLIMATION (O DAY) AND ONE TO FOUR DAYS OF HYPOKIA

\begin{tabular}{ccccc} 
& \multicolumn{4}{c}{ Hetabolites (pnole/g dry weight) } \\
Daya of Hypoxfa & Succinete & Propionate & Alanine & Stm \\
\hline-2 & 1.61 & 3.34 & 25.11 & 30.06 \\
0 & 0.95 & 2.65 & 26.88 & 30.46 \\
1 & 2.67 & 2.23 & 39.58 & 44.48 \\
2 & 3.47 & 7.02 & 42.91 & 53.40 \\
3 & 2.82 & 19.83 & 47.37 & 70.02 \\
4 & 3.12 & 33.38 & 52.69 & 89.19
\end{tabular}

Accumlation during four deye of hypoxia
2.17
30.73
25,81
58.71

of Accumulation

$\begin{array}{llll}3.70 & 52.34 & 43.96 & 100.00\end{array}$


FIGURE 7. THE TIME DEPENDENT ACCMMLATION OF SUCCINATE, PROPIONATE AND ALANINE IN GEKENSIA DEMISSA. Immediately after field collection ( -2 days), two daya acclimation w1th aerared water (0 day), one to four days of hypoxia ( 1 to 4 daya, respectively) 


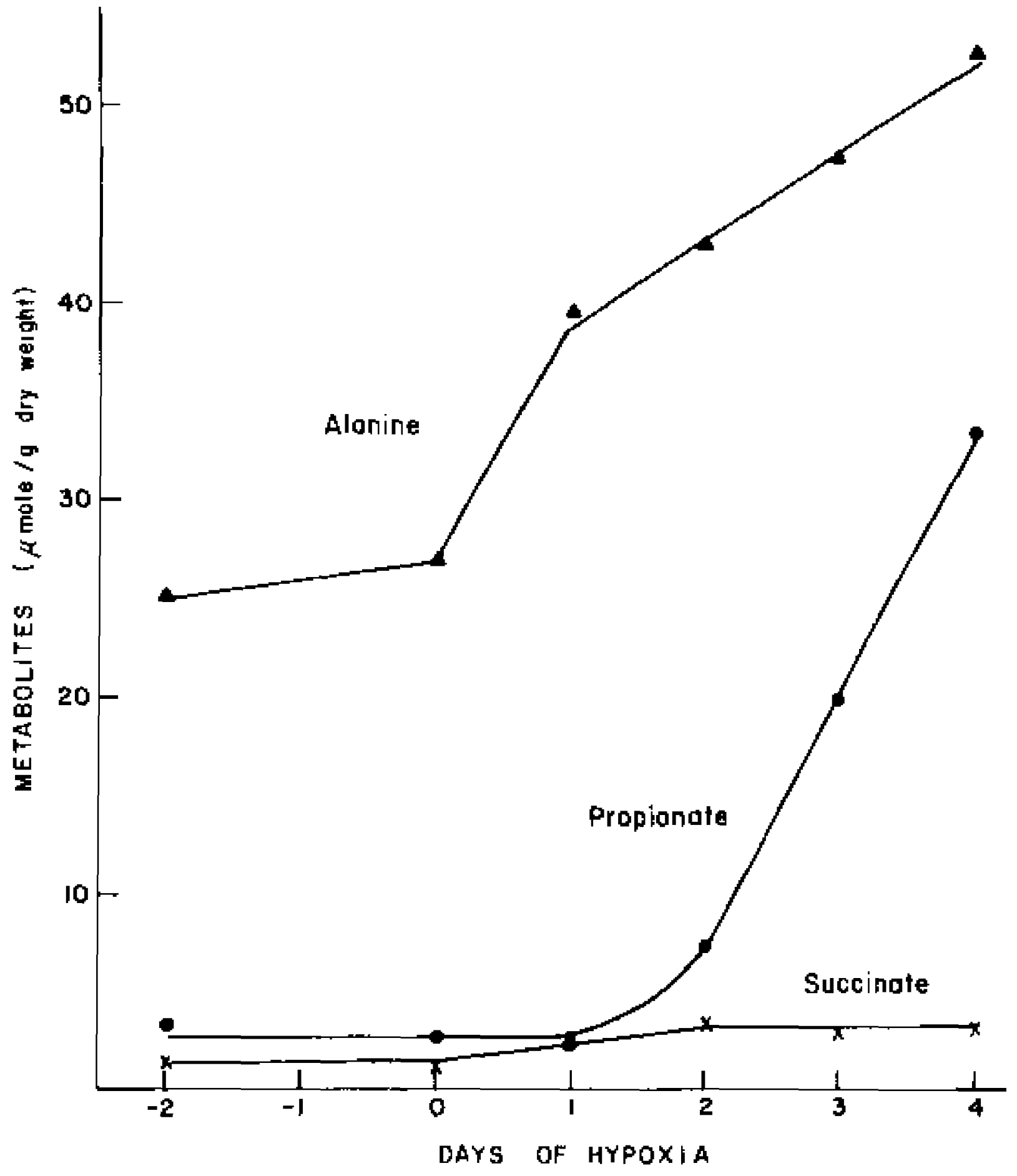


wetght after the aecond day and further Increased oharply and linearly with time of hypoxia. After four days of hypoxia, a concentration of $33.38 \mathrm{\mu g}$ wole/g dry wefght of proplante was noted. Th1e represents a ten-fold tnerease In propionate concentration (Table 17 , Figure 7 ).

The Intelal concentration of alanine wag high $(26.88 \mathrm{pmole} / \mathrm{g}$ dry welght). After the firet day under hypoxle conditione, alanine levela Increased to 39.58 pmole/g dry wetght. Fron the second day on, alower but 1Inear accumulation with time fag observed (to 52.69 fmole/g dry weight) which wag 1,96 times the or Iglnal concentration (Table 17, Figure 7 ). After four days of hypoxta, the pmolar accumulation of proplonate and glanine was ofmiler and much higher than succinate, but no lncrease was obBerved in malate, a-keto-glutarate, Loo-butyrate, butyrate, lactate and pyruvate (Table 16).

The gize and dry wetght of the mugeis uged lat this gtudy were conalotent. However, sfnce the concentrationa of polyeaccharlde were so varlable, polyaccharide content was not ugeful as a further tndicator of the effect of hypoxta. 


\section{DTSCUSS ION}

\section{Accumulation of Intermediates}

Thte study demonetrates that tigue levelo of aucclnate, prop Lonate, and a lanine Increase fn Grukena te demlasa held under hypoxic condftiona. In contrast to the vertebrateg, lactate la found not to lncreage In Gukens la demtasa under hyporic conditiong. These obgervations extend and confirm the work of other Inveatigatore who have found that other lamelifbranch molluaca,

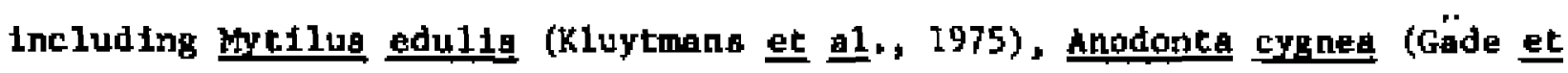
al., 1975), and Cardtum edole (Gäde, 1975), respond to hypoxic condftiong in puch the garge manner (Table 18). Therefore, it would seem apparent that the accumulation of succinate, proplonate, and alantue under hypoxic conditions 16 characterigtic of many, if not a11, iamellebrach mollusca.

Wth respect to alanire eccumblation, a wide range ta reported in this study $(3.40$ to 25.8 pmole/g dry welght) whlch repregents 7.87 to 43.967 of total accumalation (Table 18). Kluytmang et al. (1977) reported that alanine only tranatently Increaded durfag the firat hour of anoxia in wytlug edulia and then eventually diminished to near It origingl level. De zwaan and his agsoclates also auggested that glanine was only the Inftial end product of bivalve anaeroble metaboltem (de Zwaan and van Mnrrewfjk, 1973a; de Zwaan

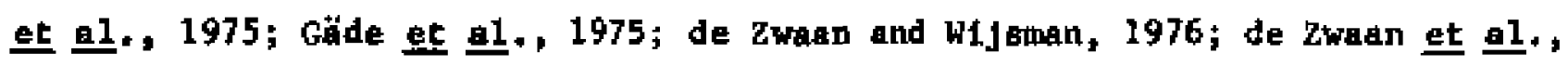
1976; Kluytona et al., 1977). Howerer, thin otudy showg a substantial Increage in the concentration of alantne from $26,8 \mathrm{~B}$ to $39.58 \mathrm{pmole} / \mathrm{g}$ dgy wetght 
durtng the f1ret day of hypokta, followed by a linear accumlation with time to 52.69 pnole/g dry weight after fout days of hypoxla (Figure 7, Tabie 17). Some evidence 1ndicates that the production of auccinate and proplonate are cortelated and that the accumulation of proptonate followe that of ala-

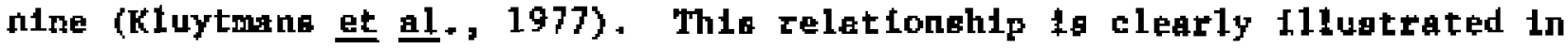
Figure 7 .

Total accumulation of buccinate, proplonate and alanine ranged from 33,00 to 75,20 pmole/g dry wefght tn the five atudies and is shown 1a Table 18. Because no elgnfficant lactate accumulation wag observed 1n any of theae studles, lactate fermentation is belfeved to have only 1 imfted lmportance (Gade et a‥, 1975).

In order to clearly obgerve these variation In metabolite concentrations, the experimental ayatemg used in this and other studies were gomewhat extrente becauge a gubmerbion of Geukenta demigsa in oxygen deficient water for two or more days would probably rarely occur 1n nature. Slnce gome varteblltty occurred In a11 atudies, there are gome likely gources of uncertainty. Among theae uncertainties, it is gtill unknow to wat extent animals in aerated water are actually reaplring, or whether they have tisoues in a hypoxic state. Gther posalble resoong for the varlation of the succinate, proplonate and alanine production are temperature (W1ddata et a1., 1979), t1ague (Chap1In and Loxton, 1976; Kluytmang and De Zwaan, 1976; Kluytmang and De Zuagn, 1977; Almmd and Chapl1n, 1977; Livingatone and Bayne, 1977), seasen (Ahmod and Chap1in, 1977), pertod of hypoxte, opecles and habltat. Th16 study of anaeroble metaboliam of Geukengle demtege wag conducted durfing both winter (December 1978) and gumer (June 1979), and the reatslts of two dayg of hypoxia at $150 \mathrm{C}$ are compared in Table 19. Although no clear 


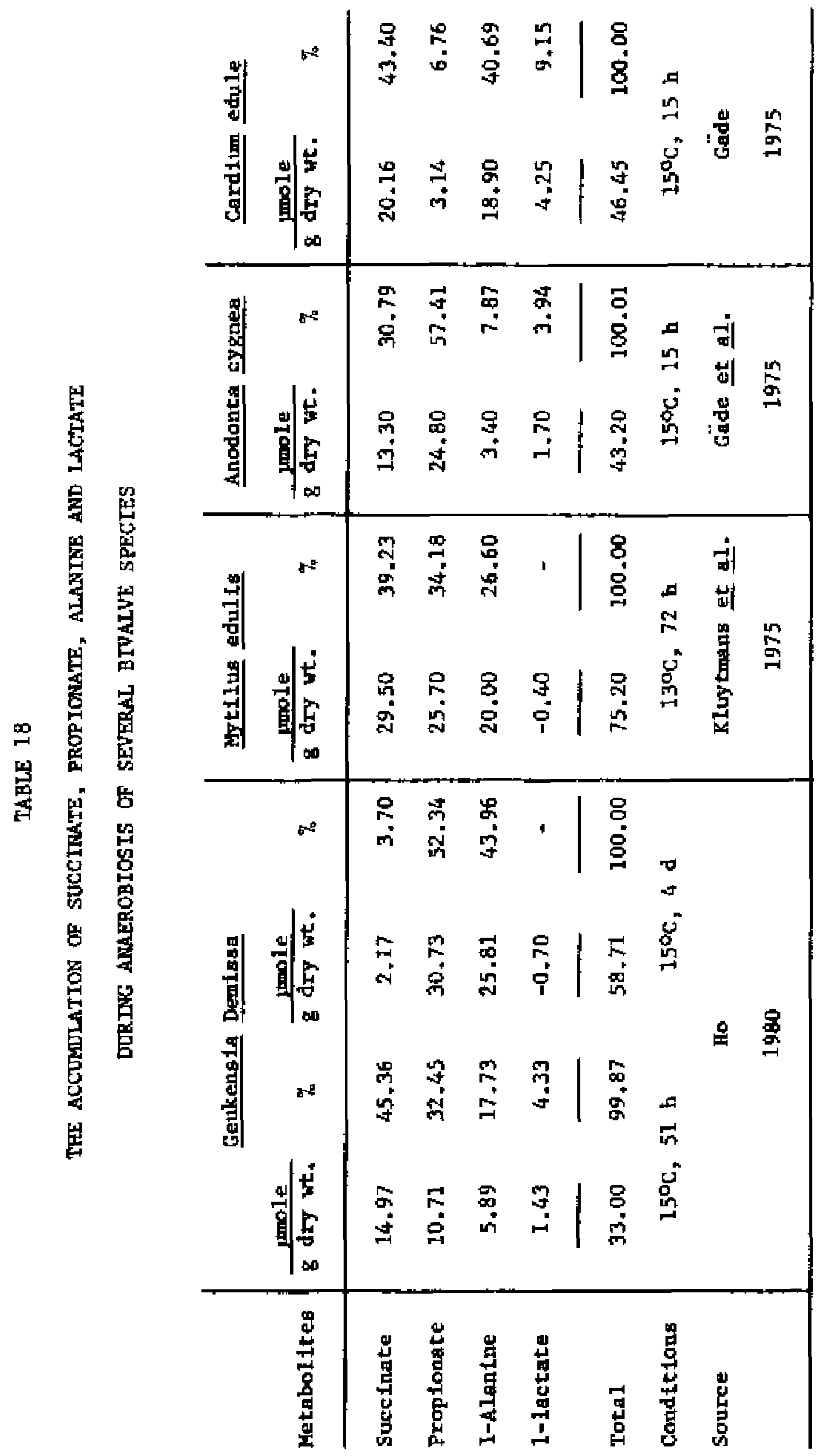


TAELE 19

CONCENTRATIONS OF POLY SACGHARIDE AND SOME METABOLTTES

OF WINTER (DECEMBER 1978) AMD SUMAR (JURE 1979)

MUSSELS, GEUKENSLA DEMESSA, AFTER TWO DAYS OF HYPOXLA

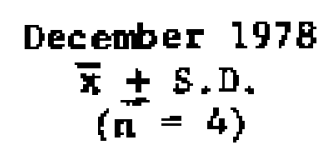

$$
\begin{gathered}
\text { June } 1979 \\
\bar{x} \pm \mathrm{S}, \mathrm{D} \\
(\mathrm{n}=3)
\end{gathered}
$$

\section{A. Condtefons}

Salinity

Disoolved oxygen

$$
17.10 / 00
$$$$
\text { <0.04 Ppr }
$$

$14.40 / 00$ $0.04 \mathrm{ppm}$

B. Hugelo (polyagccharide in mg/g dry wetght)
Size (crs)
Dry welght (g)
Polyaacchar 1de
$11.13 \pm 0.25$
$2.52 \pm 0.37$
$84.50 \pm 34.10$
$11.67 \pm 1.04$

\begin{tabular}{|c|c|c|c|c|}
\hline $\begin{array}{l}\text { Sucelnate } \\
\text { Malate } \\
\text { a-keto-Glutarate } \\
\text { Froplonate } \\
\text { Lao-Butyrate } \\
\text { Butyrate } \\
\text { lao-Velerate } \\
\text { Alanine } \\
\text { Lactate } \\
\text { Pyruvate }\end{array}$ & $\begin{array}{r}19.63 \pm \\
2.78 \pm \\
0.38 \pm \\
14.16 \pm \\
1.18 \pm \\
1.09 \pm \\
0.19 \pm \\
71.09 \pm \\
6.43 \pm \\
0.57 \pm\end{array}$ & $\begin{array}{l}13.03 \\
1.15 \\
0.29 \\
6.48 \\
0.42 \\
0.20 \\
0.06 \\
7.21 \\
1.71 \\
0.34\end{array}$ & $\begin{array}{l}3.47 \pm \\
1.70 \pm \\
0.05 \pm \\
7.02 \pm \\
0.50 \pm \\
0.71 \pm \\
42.91 \pm \\
4.86 \pm\end{array}$ & $\begin{array}{l}2.28 \\
0.53 \\
0.01 \\
2.68 \\
0.16 \\
0.17 \\
4.15 \\
1.21\end{array}$ \\
\hline
\end{tabular}
$3.31 \pm 0.04$ $152.65 \pm 16.58$

C. Metaboliteg (ymole/g dry wefght)

D. Stm of thetaboltteg (jmole/g dry welght)

$$
117.48
$$

61.22

E. Sum of guccinate, proptonate and alanine (pmola/g dry weight)

$$
104.87
$$

53.40 
conclusion can be derived concerntng temperatute and aeabonal effecta, concentrations of all metaboliteg wate higher in winter than in gumer nusgele. Thlo dfference may be partially attributed to galintty (17.1 o/oo In Decenber $197 \mathrm{~B}$ and 14.4 o/oo in June 1979) or, more likely, the chang1ng phygiologIcal gtate of the organismg durtng the warmer pertod.

\section{Concentrat 1ong of Krebs Cycle Intermediatea}

The abundance of Krebs cycle fotermediateg in varlous tiagueg of Craggogtree virgintca and wole Geukengia demlega deternined In thIs atudy Is show in Table 6 , thoge of Craggogtree yirgtnica mantle and other organ= Lamg are compiled tn Table 20. Although precige comparison may be inapproprlate becauge of vartations in experimental condtions and analytical nechoda, acte tendencles are noteworthy. Succinate concentration In mole/g wet welght varied from 38 to 510 lin Geukengle denlega and from 139 to 479 in Cragegetrea virglnica aa determined 1n this study (Table 6). Succinate was much lower than the 29,661 mole/g wet wefght in oyster mantle reported by Hampen and Wflbur (1959) but wag oLmflar to 240 in wytlug edulig (De Zwaan and Zandee, 1972b). Concentrationa of Kreba cycle Intermediateg In Crabgogtrea virglnice and pytilug edulig determined from thig atudy are also comparable to those of rat (Kukala and PrLoreacht, 1967) and guinea ptB. (de S11va, 1971).

\section{Mecabolle Scheme For Holluacan Anaerobiogig}

Aa a conceptua1 tool for focus Ing on fut ther exper Imentation in angeroblogis wth lamelitbranch molluaca, the following hypothettcal acheme (F1gure 9) which buflda on that of other workere (G111es, 1972; Hochechka and Husafa, 1972; Hochachke et al., 1973; De Zwan et al., 1973; De Zwaan et aㅡ., 1976; Hochachka, 1976; Collicutt and Hochachka, 1977) ia propoged, The anlient 


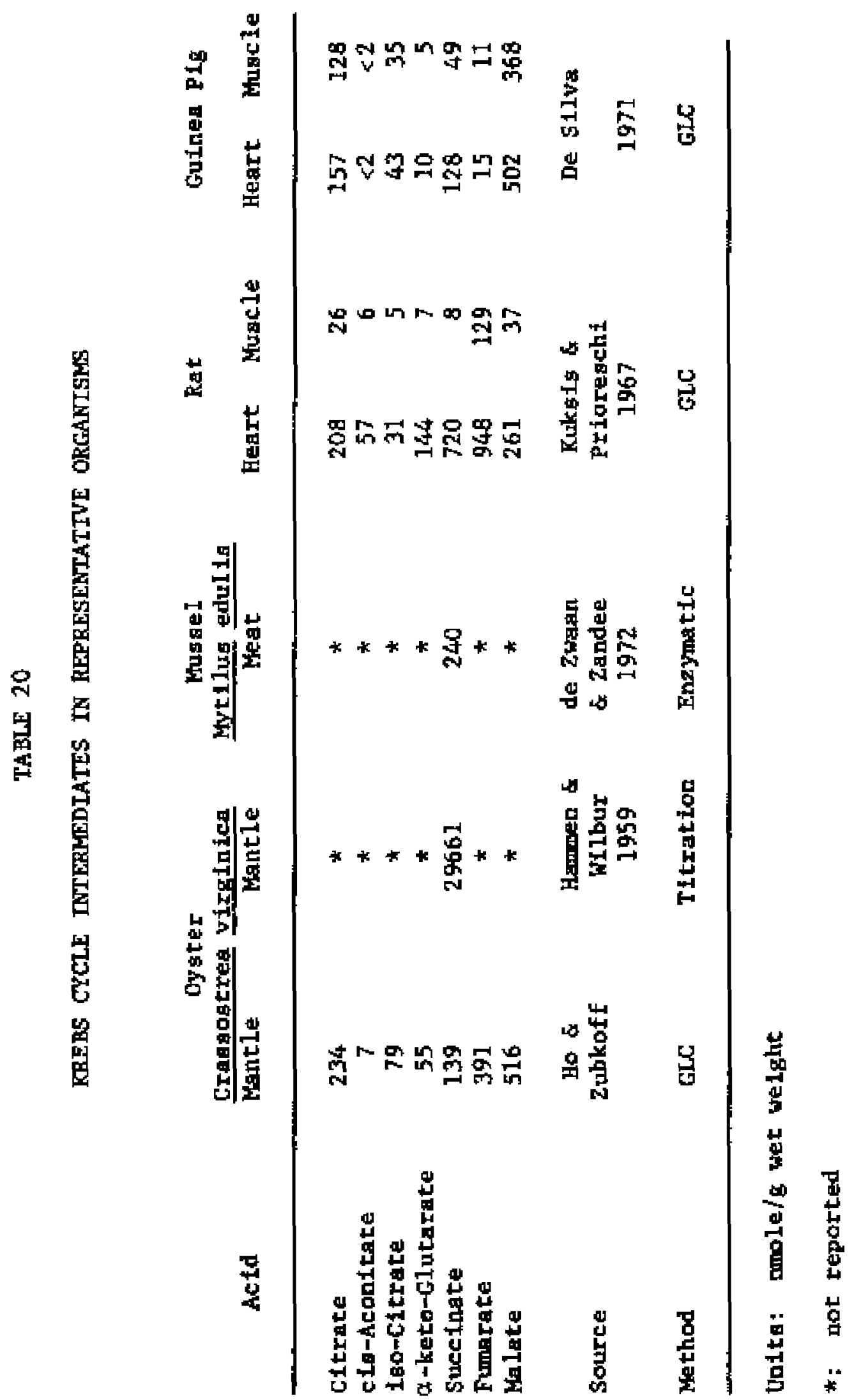


FIGURE 8. A WPOTHETICAL SCHEME OF GEUKENS IA DEMISSA ARAEROBIC META BOLISM.

Double lined box ta mitochondrion. 


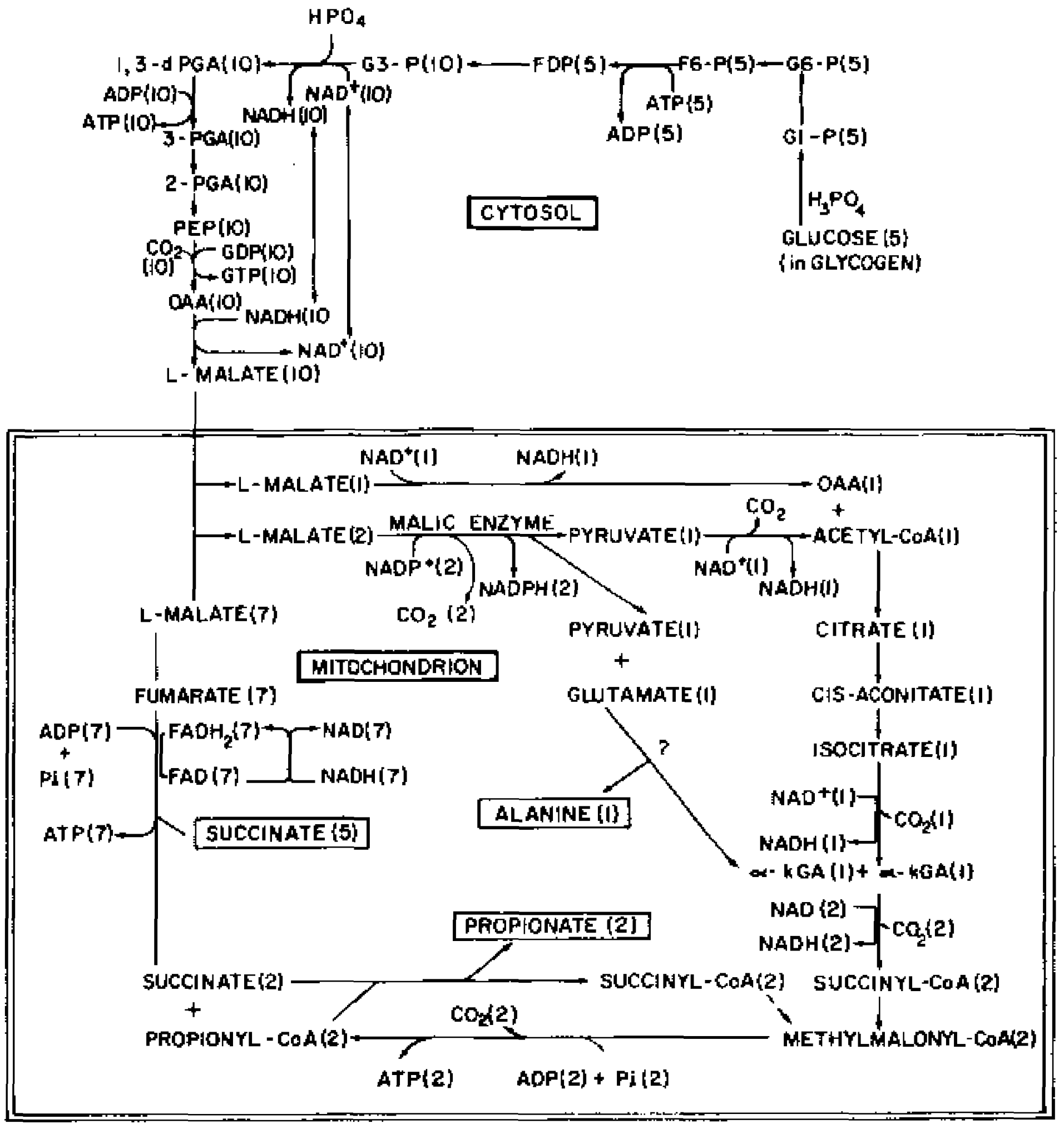

OVEAALL REACTION:

5 GLLCOSE + I GLUTAMATE + 2 COn +24 AOP + 24 PL
5 SUCCINATE + I ALANINE + 2 PROPIONATE

2 SUCCINYE- COA + 24 ATP 
features of this scheme are:

(1) the Embden-Meyerhof-Parnas scheme of glycolya18,

(2) carbon dioxide fixatian,

(3) the Kreba cycle,

(4) transamination,

(5) part of the electron transpore chafn for fumarate reduction, and

(6) methyl malonyl-Co $A$ as an 1ntermediate In the formation of proplanate.

This information 1a advanced one step further with reapect to cytoeslmItochodrial compartmentation and redox balance. To date, this is the only bivalve anaerobte metabolic scheme which contalng all these esgential considerationa and differs from othera by achieving redox batance.

As a point of reference, th1s proposed scheme starts from g1ycogen. Glycogen, known to be the mogt fmortant carbohydrate regerve for blvalve metaboliam, is broken down to pyruvate via the Embden-Meyerhof-Parnas pathways. At this point, the majot branchpoint of aerobfe and anaerob1c metab= ollem In the cytogol is reached. Th1s branchpoint 1e controlled by pyruvate kfnase for pyruvate formation and by phosphoenolpyruvate carboxykinase for oxaloacetate formation, a component of the krebs cycle.

The Krebs cycle could also be entered by the formation of malate, catalyzed by the action of mal1c enzymo on phoophoenolpyruvate and carbon dfoxide. Malate may be able to cross the mitochondrial membrane, as in higher organfing (Lehninger, 1970) and thus, the reactions of the cytogol may be coupled through thla aubetrate. Malate dehydrogensoe has been local1zed In both the cytosol and the mitochondrion of the glant gcallop, Flacapecten magel lanicug ('Doherty and Feltham, 1971). 
The further convaraton of malate to auccinate by reveraal of the oteps of the Krebs cycle hag been extenalvely atudied. Thege oteps are catalyzed by fumarage and fumarate reductage. Both enzymen have been localtzed In the mitochondrion of the clam, Rapgla sunegta (Chen and Awapara, 1969) and the scallop, Placopecten ㅁagellanlcue (0'Doherty and Feltham, 1971), and Nyt1lug edu119 (Addtak and Veenhof, 1975). In thie pathway, high energy phoophate 1B generated and MADPH Is produced by geveral reductive atepg in the mitochondtion.

In considering the pivital role that malate may agsume fn enaeroblogis, the partial sequence of the Krebs cycle (malate * oxaloacetate + cttrate + Lao-c1trate * a-keto-glutarate) has been Incorporated in this hypothetical anaerobfe gcheme. Th1 10terpretation differs from that of Hochachke and his asgoclateg who argued that a1though citrate aynthetage has normal activity fo mollugcan tiogue, these reactions were undesirable under anoxic conditions becauge an Increase in the reductive state of the cell would regult (Hochachka et eㅡ, 1975; Ftelda, 1976; Fielda et al., 1976; FLe1da and Hochachka, 1976; Baldwin, 1978). In the scheme proposed here (FIgure 8 , inside box), redox balance is malntalned wth these forward reactions and ATP can be generated by reoxidizing NADH. other enzymea which catalyze these reactiona malate dehydrogenase (0'Doherty and Fe1tham, 1971); malate enzyme (de Zwaan and Van Marrew1jk, 1973b)j 1socttrate dehydrogenfae (Addink and veenhof, 1975) have been detected tn the molluscen mitochondrion.

In contragt to the central position of malate in anaerobiosts, a11 atudies on bivalve anaeroble metabollgm have detected a certaln degree of alantne accumulation (Table 18). The gource of the alanine te st111 
questlonable but, at present, the trangamination of pyruste with anano acida Lo the most widely accepted gcheme. The enzyme, alanine anlnowtransferabe, localized In wollugcan mttochondria (Addint and Veanof, 1975), Is Indirect evidence In oupport of trangamination as che source of alanfor formation. However, alternatlve schemes, wuch as the alanine debydrogensse reaction, have not been carefully examined. Alanine plays an Lmportant role Ln regulation of aeroblc and anaeroble metabollgm becauge it 1s a atrong Inhibltor of pyruvate kinese activity and 1s positiva modulator to phosphoenalpyrurate carboxykinase (Mustafa and Hochachka, 1973a, b).

As 1n the case of atanfre, ptoplongte acctindateg but with a different tLpe course. The mechastan of proplongte formation in anseroble tiasue has beer recently atudied In parasitlc helmintho (Tkachuck et at., 1977; Saz ef a1., 1978). Avallable evidence ig consibtent with the followirg scheme;

$$
\begin{aligned}
& \text { Succ Iny1-CoA } \quad+\text { Methylmalonyl-CoA } \\
& \text { Methylmalonyl-CoA }+\mathrm{E} \rightarrow \mathrm{CO}_{2}-\mathrm{E}+\text { Prop Iony 1-COA } \\
& \text { Proptony 1-CoA + Succ Inate + Prop Lonate + Metbylmalony I-CoA } \\
& \mathrm{CO}_{2}-\mathrm{E}+\mathrm{ADP}+\mathrm{PL}+\mathrm{CO}_{2}+\mathrm{ATP}+\mathrm{E} .
\end{aligned}
$$

Sum

$$
\begin{array}{cc}
\text { Succlnyl-CoA }+ \text { succinate } & + \text { Proplonate }+ \text { Methylmalonyl-CoA } \\
+ \text { ADP }+ \text { P1 } & +\mathrm{CO}_{2}+\operatorname{ATP}
\end{array}
$$

Although the metabolic formation of proplonate In molluacs has not been examined, te 1s not unreasonable to postulate a etmilar pathway. 
In addition to the accumilation of intermediary metrboliteg and the enzymes agsoclated wth them. redox balance 1s alao an tmortant consideratlon. To fecllitate the digcueston of redox balance, energy-rich phopphate generation, metabolite accumslation and compartmentation, numbers are aragned to thege corpounds in the model (Figure 8). In keeping with carbon balance, it is agsumed that one mole of glutamate Ig mobilized simultaneougly with every five moles of glucoatdes constgmed. A balance Bheet ia preaented fn Table 21 there tedox balance la milatalned oeparately in the cytogol and the mitochondrion. The overal1 reaction may be written as;

5 Glucosides + 1 Glutamate $+2 \mathrm{CO}_{2}+2 \mathrm{CoASH}+24 \mathrm{ADP}+24 \mathrm{FH} \rightarrow$

5 Succlrate +1 Alanine +2 Proplonate +2 Succinyl-CoA + 24 ATP .

In the above scheme (9), Blutanate may be in an 1nternal pool or derived from protein decomposition. Carbon doxide may be abeorbed from water or generated by decalelfecation of the she11 under the anoxie condtion, as proposed by Crenghaw and Heff (1969) and W1jaman (1975) for Mytilus edul1a. of the 24 ATP generated, feven are obtained through oxidative phosphorylation as a regult of the flavin-linked fumarate reductane reaction (Saz, 1971), whereag the otherg are all through subatrate phosphorylation. The energy efficiency 1s 4.8 molea of ATP from the almultaneoua consuption of one wole of glucoge and one-fifth mole of Blutanate; comparable effictency was eatimated as alx moles of ATP fron each mole of glucose by De zwaan et al. (1976).

Furthermore, the two moles of auccloy1-CoA may be converted to propion* ate; thus, the overall reaction for the next five moles of glucosides is: 
TAFLE 21

BALANCE SHEET OF AIAEROBIC METABOLISM OF

GELKENSIA DEMISSA ACCORDING TO THE HYPOTHETTGAL SCHEME

$\begin{array}{llcc}\text { Reget Iont } & \begin{array}{c}\text { NADH } \\ \mathrm{FADH}_{2}\end{array} & \begin{array}{c}\text { Energy Rtch } \\ \text { Phosphate }\end{array} & \begin{array}{c}\mathrm{CO} 2 \\ \text { Production }\end{array}\end{array}$

A. Cytop1asm

Glucoside (5) (In Glycogen)

$F-6-P(5)+F O P(5)$

$\mathrm{G-3-P}(10) \rightarrow 1,3-\mathrm{dPGA}(10)$

$1,3-\operatorname{dPGA}(10)+3-P G A(10)$

PEP (10) $\rightarrow$ OAA (10)

OAA (10) - Halate (10)

$\begin{array}{rr}10 & -5 \\ & 10 \\ -10 & 10\end{array}$

B. Mitochondrton

Glutamate (1) moblilzed

Halate (1) $\rightarrow$ OAA (1)

Halate (2) + Pyruvate (2)

Pyruvate (1) + Acety1-CoA (1)

1ao-Citrate (1) + a-kGA (1)

r-kOA (2) $\rightarrow$ Succiny $1-\operatorname{CoA}(2)$

Methy lma lony 1-CoA (2) $\rightarrow$ Proplonyl-CoA (2)

Fuarate $(7)+$ succinate $(7)$

1

2

1

1

2

$\begin{array}{lll} & 2 & 2 \\ -7 & 7\end{array}$

Stm

0

24

$-2$

5 Glucosides +1 glutamite $+2 \mathrm{CO}_{2}+24$ ADP $+24 \mathrm{PI}+26 \mathrm{CoASH}+$

5 Succlnate + 1 Alanine + 2 Proplonate +2 Succinyl-CoA + 24 ATP 
5 Glucosides +1 Glutamate +2 Succinyl-CoA +2 CoASH +26 ADP +26 P1 +

3 Succtuate + 1 Alanine + 4 Proplonate + 4 Succinyl-CoA + 26 ATP .

Proplonate formation 1a coupled with succinate ag ahown In this model (F1gure 8). Thus, thia cotpling may explain the lag of proplonate accumlation and the non-accimmlation of succlante under the hypoxic condition (Figure 7). In contragt to anaeroblc mollugen metabollam, the pathways of aeroble metabolibu tn molluber nould be similar to that of higher organiame, The net reaction may be written ar:

1 Glucoside $+6 \mathrm{O}_{2}+6 \mathrm{CO}_{2}+6 \mathrm{H}_{2} \mathrm{O}+37 \mathrm{ATP}$.

Of the 37 moles of ATP generated aerobically (Lehn1nger, 1970), 32 moles are through oxtdatie phosphorylation with oxygen as final electrob acceptor, the primary reagon for the Breater efficiency of aerobic metabollgm. Thus, bivalve anaeroblc metabolism is somewhere between the hLgly efflelent aerobic metaboliam and the lega efficlent production of ethanol by feraentation or accunlation of lactate by anaerobte macle glycolyata.

Although anaerobic metabolism as presented here $1 \mathrm{a}$ only $13 \%$ as efficlent ag aeroblc metaboliam in energy praduction, there wag no clear Indication of Encreased glucose conaumption under the hypoxfc condition. A posalble explanation 1s that bivalvea may decrease their energy utilization under oxygen deficlency, ag augge日ted by MeCarthy (1969), Heyne (1971, 1973, 1975),

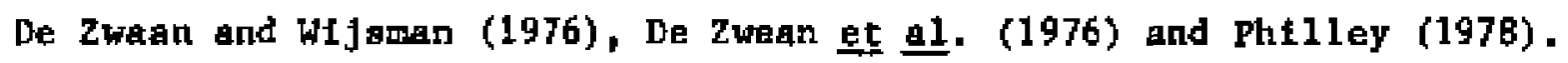
In conclueton, this otudy determined that eucelnate, proplanate and alanine accumulated when the ribbed musals, Geukengta demlase were held hypoxically. This result is contatent with thoae obtained for Hytilus edulig, Anodonta cysnea and Cardim edule by other 1mvestigators. Thus, the evidence presented from this atudy and that of the licerature Indicatea that mogt bivalve mollugcs have atmilgr metabalfo pathwaya. 


\section{SIMHARY}

1. Anferobic metabolism has been Itwestigated in the Intertidal bivalve, Geukenala demiaga, In order to generalize and elaborate on earlier

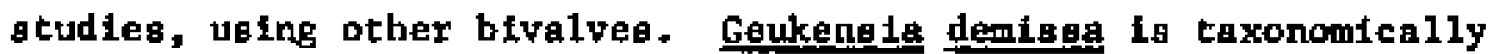
and ecologfcaily atmilar to tyt1lug edulig and anaerobic metabolism to belleved to be esential for aurvival durfag atr exposure perioda.

2. Specimeng of Geukengla demlega were mafntained In elther aerated or hypoxic water for up to four days. Mafor metaboliteg and polyacchat lde of each musel were then anslyzed and compared.

3. To date, this ia the firat atudy of bivalve anaerobic metabolian in which all thoge compound were meagured In each Endividual organimm inatead of pooled tiggueg.

4. Bath defined term and time courae otudies were conducted ustng migels under winter and gumer conditions.

5. A gensitive gas-11quid chromatographle method which analyzes oeven Rrebs cycle Interwediates gtmultaneously was adopted for this trvestigation after batiofactory teata with ayatera, Crasaobtrea virginica. Within the group of Krebs cycle Intermediatea, only succinate hag been anglyzed by other Imostigatore of bivalve anaerabic metaboliam. 
6. In Geukengla demigsa, oucc 1nate, proplonate and alantne accuwlated hypoxicaliy but not malate, a-keto-glutarate, cle-aconitate, c1trate, 1вo-butyrate, butyrate, too-valerate, lactate or pyruate. The polygaccharide content of each musel wa quite different and did not show a clear Indication of decraase under the hypoxtc condition.

7. Proptonate production was shown to follow succtnate accumslation, which corroborates an earlier report for yytilue edulte. The 11near Increase of alanine concentration wth tncreasing duration of the hypoxte perlod obaerved in this atudy has not been reported previously.

8. Results obtained from this otudy are conglatent with those derived for Ift11ub edu1fg. Anodontes cyshea and Gardium edule by other 1mventigators. Thus, these data suggegt that anflar angerobtc metabolic pathwaya exiat among bivalves.

9. A hypothettcal schene of bivalve nnerobic metaboliem 1a propoeed in which redox balance Ia achleved Ln both cytosol and mitochondria. This acheme Incorporates parts of the Embden-Heyerbof-Parmas dycolyt Le pathways, carbon dtoxide flxation, the Krebs cycle, trangamination and pathwyg for proptonate formatiots. To date, this to the only bivalve anaeroblc metabolic gcheme which containg all these enaenttal conalderatione. 


\section{BIBLICGAAPHY}

Addink, A.D.F. and P.R. Veenhof. 1975. Regulation of mitochondrial matrix enzymes in tytilus edulte $L$. $p$. I09-119. In H. Barnes (ed.), Proc. 9th Eurge. Mar. BIol. Syme. The Aberdeen Univeratty Press, Aberdeen.

Ahmad, T.A. and A.E. Chap11n, 1977. The Intermediary metaboliam of Mrtilua edulig (L.) and cerastoderma edule ( $L_{*}$ ) during exposure to the atmoaphere. Bfochem. Soc. Trans. 5:1320-1323.

Augenfe1d, J.M. 1966. Lactic dehydrogenage activities in tmvertebrates tn relation to environment and mode of gas exchange. Comp. Biochem. Phya1o1, 18:983-985.

BaIdwtn, J, and A.M. Opte. 1978. On the role of octoptne dehydrogenase tn the adductor macles of bIvalve mollugcs. Comp. Blochen. Phyalol. $61 \mathrm{~B}: \mathrm{\theta 5}-92$.

Bayne, B.L. 1971. Venttlatton, the heart beat and oxygen uptake by wytt1ug edulig In declining oxygen tension. Conp. bJccliem. Phystol. 40:10651065.

Boyne, B.L. 1973. Aspects of the metabolikm of pytilug edulis L. during etarvation. Heth. J, Sea Res, 7,399-410.

Bayne, B.L. 1975. Aapecte of phyelologlcal condtton In tyctlug edulia L., wth spectal reference to the effecte of onysen tension and salintty. P. 213-238. In H. Barmeg (ed.), Proc, 9th Europ. Mar. Blol. Syup. The Aberdeen Untueralty Preas, Aberdeen.

Booth, C.E, and C.F. Mangum, 1978, Oxygen uptake and tranaport in the

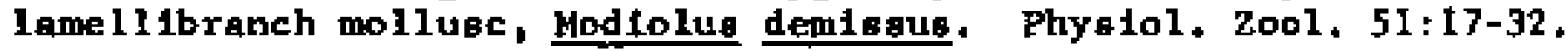

Brand, T. von, H.D. BaernsteLn, and B. Hehlman. 1950. Studfer on the ankeroblc metaboliam and the aerobic carbohydrate consunpt lon of gowe fregh water snatla, Btol, Bull, Woods Hole 9B:266-276.

Chaplin. A.E. and J. Loxton. 1976. T1asue differences In the reaponat of

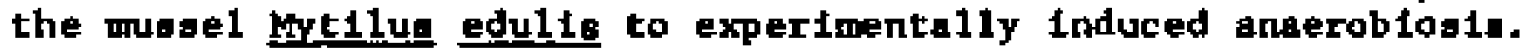
Blochem. Soc, Trang, 4:437-441.

Chen, C. and J. Awapara. 1969. Intracellular dfatribution of enzymes catalyzing auccinate production from glucose In Rangle mantle. Coup. Blochem. PhyaLo1, 30:727-737. 
Col11cutt, J.H. and P,W. Hochachka. 1977. The anaeroblc oyater heart: coupling of glucoge and agparcate fermentation. J. Comp. PhysLol. B. Hetab. Tranap. Funct. 115;147-157.

Crenghaw, M.S. and J*H. Neff, 1969. Decalclfleation and the mantle-ghel1 Interface in thollubea, Ath, 20o1, 9;8B1-895.

E11fngton, W.R. 1977. Aeroble and anaeroblc degradation of glucose by the

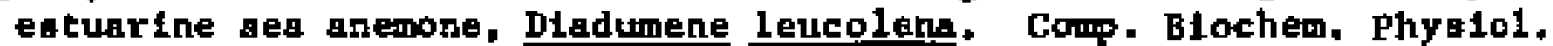
5BE: $173-175$.

FIelda, J.H.A. 1976. Enzymes of the eltrate btanch polnt In the adductor ruscle of the oyster. Ph.D. Thesis, University of Britiah columbia,

Flelda, J.H.A., H, Guderley, K, B, Storey, and P.H. Hochachka, 1976 . Oetopua mantle citrate synthage. Can. J. Zool. 54;8B6-891.

Fielde, J.H.A. and P.W. Hochachka, 1976. Oygter cltrate gynthase; control of carbon entry Into the Kreba cycle of a facultattre anaerobe. Can. J. zool. 54:592-595.

Gäde, G. 1975. Anaetoble metaboliam of the common cockle, Cardium edule. I. The utilization of glycoger and accumulation of multiple end products. Arch. Internat, Physio1, Btochem, 83:879-886.

Gäde, G*, H. Wt1PG, J,H,F,M. Kluytmane, and A, de Zwan, 1975 , Glycogen degradacton and end ptoducta of anaeroble metabolism 1 n the freah water bivalve Angdonca cygnea, J. Com. Phya1o1. 104:79-85.

Gibte, B.F., K, Itlabe, J,G, Crawhal1, B.A. Cooper, and O.A. Mamer. 1973. A rapid gaf chromatographic method for the quantitation of volatile Fatty acidg in wrine. Proplonic acid excretion in vitamin B12 defleleney. J. Chromatogr, 81:65-69.

Gitles, H. 1972, BtochemLcal ecology of toollusca. Chem. 2001, 7:467-495.

Gruner, B. ant E. Zebe. 1979. Studieg on the anaerobtc metaboltam of earthworms. Comp. Blochen. Physiol, 606;441-445.

Hatmen, C.S, 1966, Carbon dioxide flxation In marlne twvertebrates. W, Rate and pathway in the oyster, Couq. Blochem. Physiol * 17:289-296.

Hammen, C,S, and K,M* Hilbur. 1959, Carbon dioxide fixation In marine Invertebrates. $I$, The matn pathway in the oygter. J, Blol. Chem, $234 \div 1265-1271$.

Ho, M,-S. and P.L. Zubkoff, 197B, GaA 11quid chromatographle quantification of the Krebs cycle Internedlates in the mantle tlogue of the Amertcan

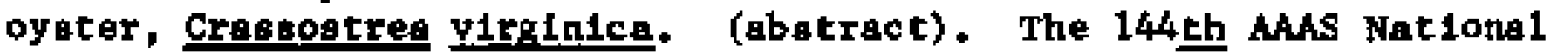
Heeting In Waghington, D,C.

Hochachka, P.W. 1976. Deatgn of metabolic and enzyule machenery to fit Iffestyle and emviroment. Btochem. Soc. Syup. 41:3-31. 
Hochachka, P.W. and T. Muatafa, 1972, Invertebrate facultative anaerabioaLa. sctence $178: 1056-1060$.

Hochachka, P.W. and G.N. Somero. 1973. Strategles of Blochenical Adaptation. 358 P. W. B. Saundera Co., Ph1ladelph1a, London, and Toronto.

Hochachke, P.W, J. Fleldg, and T. Yutafa, 1973, Animal 11 fe wtthout orygen: Basic blochemleal metabollama, An. Zoolog1at 13:543-555.

Hochachka, P.H., K.B. Storey, and J. Baldwin, 1975. Squ1d muele cttrate Byathase: control af carbon entry thto the kreba cycle. Conp. Blochart. Phyetol. 52B:193-199.

Kluytmang, J*H*, P.R. Veenhof, and A. de Zwaan, 1975. Anaerobic production of volatile fatty acids in the aea musal, Hytilua edulla $L$, J, Comp. PhyaLa1. 104:71-78.

Kluytmans, J.H.F.H. and A, de Zwaan, 1976. Production of volatile fatty acid. In bevalved mollubes, Biochem. Soc. Trans. 4:475-477.

KLuytmana, J.H., A.M.T. de Bont, J. Janus, and T,C.M, HIJaman, 1977, T1me dependent changes and tiave opectficteles in the accumulation of anaeroble fermentation products in the gea misgel Myt1lus edulig $\mathrm{L}$. Comp. Btochem. Phystol. 58B:81-87.

Kuenzler, E.J. 1961. Structure and energy flow of a musael population In a Georgla galt marah, Limnol, Oeeanogr, 6:191-204.

Kuka1a, A, and P. Prloregchl. 1967. I golation of Kreba oycle acida from tiegues for gas chronatography. Anal. Blochen, 19:468-480.

Lehninger, A.t. 1970. Blochemistry. 833 p. Worth Publighara, Inc.. New York, N.Y.

Lent, C.H, 1967. Effect of hab1tat on growth indices in the ribbed musel, Modiolub (Arcuatula) demisbug, Chesapeake Sc1. B:221-227.

LAvingatone, D.R. and B.L. Bayne. 1974. Pyruvate kinage from the mantle tibue of MytIlug edul1s L. Comp. Btochem. Phys1ol, 485:481-497.

LIvingetone, D.R. and B.L. Bayne. 1977, Responges of tytilup edulte L. to low oxygen tenalon: anaeroble metabolism of the postertor adductor mucle and mantle tiesues. J. Comp. PhysLol, 114:143-155.

Loxton, $J$. and A.E. ChapI 1n. I973, The metabol tem of prtilus edul1e $L$. durfng factultative anaeroblobls. Blocher. Soc. Trans. 1:419-421.

MeCarthy, R.M. 1969. The carbohydrate metabolism of the clam, Wya arenarta, Ph.D. Theate. Georgetown Uatveratty.

Mehlman, B, and $T$, von Brand. 1951. Further studieg on the anaeroble metabol fam of some fregh water anat1s. Blol, BuI1. 100:199-205. 
Mogre, H.B. 1931. The muda of the clyde mea area. III. Chemfcal and physlcal conditions; rate and nature of gedtmentation; and fauna, J. Mar. Btol. Ase, U.K. 17:325-35B.

Mustafa, T* and P.H. Hochachka. 1973a. Enzymes In facultative anaeroblosts of mollugce. II. Baste catalytic properties of phosphoenolpyruate carboxykinaee in oyster adductor muscle. Comp, Blochem, Phyelol, 45B: 639-655.

Hugtafa, T, and P.H. Hochechka, 1973b, Enaymeg of facultative anaeroblogte In molluacs. III. Phosphoenolypyruvate carboxyktnage and tte role in aerobfe-angerobic tranation. Corp. BLochem. Phyb1ol. 45B:657-667.

O'Doherty, P.J.A. and L.A.W. Feltham, 1971, Glycolys 1g and gluconeogenesis In the gfant acallop, Placopecten magellanicug (Gne11n). Conp. Blochem, Phy io1, 398:543-551.

Pbilley, J.C. 197B. Anaerobic uptake and utilization of g1yc1ne-2-14C by the estuarine blvalve Rangla cuneata at three galinttiea, Comp. Blochem. Phys1o1, 61:565-569.

Read, K.P.H. 1962, Trangamlnation in certain tiaue homogenates of the bivelved mollueca tyttlua edulie $L$. and Hodlolua modlolua L. Comp. B1ochen. Physto1, 7:15-22,

Saz, H,J, 1969. Carbohydrate and energy metabolism of nematodes and Acanthocephala, Chem, Zool, 3:329-360.

Saz, 9.J. 1970. Comparative energy metabolfam of some parastic helmintha. J. Paragit. 56:634-642.

Sax, fi.J. 1971. Facultative anaerobfosis in the Invertebrates: pathwaya and control ayetems. Am. Zoolog 19t 11;125-135.

Saz, H.J,, G.A, Dunbar, and A,E, Gardner, 1978. Proplonate formation from aucclingte and pogstble ATP generation, Abstract. The American Soclety of Paraitologigt Meeting. ChIcago, Illinola,

Schöttler, u, 1975, ẗ̈ber den AnaerobLonestoffwechel von Tubtfex. Verh. dt. 2001. Ges, 1974:271-274.

Schöttler, U, 1977a. The energy-yleldLng oxidation of MaDH by fumarate in anaeroble mitochondrta of Tubtfex ep. Comp. B1ochem. Phystol. $5 \mathrm{BB}: 151-156$.

Schöttler, U. 1977b. MADH-generating reactions tn anaeroble Tubtfex mitachondrla, Comp. Blochem. Phyalol. 58B:261-265.

Schöttlar, U. 1978. Investigatlong of the anaeroble metabolism of the polychaete worm Nerele diversLcolor M. J. Comp. Physiol. 125: $185-189$. 
Schöttler, U. and G. Schroff. 1976. Unterauchungen zum anaetoben Glykogenebbau beI Tublfex tubLfex M. J. Comp. Physiol. 101: 133-145.

Schutgens, K.B.H, C.T. Awle, F.A. Beemer, and W.J.M. Berntssen. 1977. Rapid ensyle rrictomethod for the quancitative determination of $\mathrm{L}=$ (+)-alanine In blood and urine, clin. Chim. Acto 80:1-5.

SIgma Chemical company . 1977. The quenttetave determination of pyruvic actd and lact le acid lit thole blood at $340 \mathrm{~mm}$, Tech, Bull * 726-ur and $826-\mathrm{UW}$.

Stlva, E.H. de. 1971, Analyata of Krebs cycle and related ac1da 10 gutnea plg tiasueg by gar-1Lquid chromatography. Anal, Chem. 43:103t-1035.

Stokes, T.M, and J, Awapara. 1968. Alanlne and aucclnate as end-producto of Blucoge degradation $\mathrm{n} n$ the clam Rangia cuneata. Coup. Btochem. Phyatol. 25:B83-892.

Strholt, B. 1977. Production of volatile fatty acida In the anaerobic catbohydrate catabollam of Arenlcola marlne. Comp * Blochem. Phyolol. 58B : $147-150$.

Theede, H., A. Ponat, K. Htrokt, and C. Schlieper, 1969. Healstance of marine bottom Imvertebrates to oxygen deftctency and hydrogen aulfide. Mar. Blol, 2:325-337.

Tkachuck, R, D*, H.J. Saz, P.P. Welnatein, K. Finnegan, and J.F. Hueller. 1977. The pregence and posatble function of methylmalonyl coA mutase and proptonyl CoA carboxylage In Splromatre mphanoldeg- J. Parasitol. $63: 769-774$.

Hegener, A., A.E. Barnitt, and C.S. Hammen. 1969. Reduction of fumarate and oxtdation of aucelnate in Cragogatren virgtnica (Gmelin). LIfe Se1. 8:335-343.

Widdows, J., B.I. Bayne, D.R. LIvLngatone, R.I.E. Newe11, and P. Dorkin. 1979. PhyaLologloal and blochemical reapongeg of bivalve molluece to expogure to alr. Corp. Blochem. Physiol, 62A-301-308.

H1jaman, T.C.M. 1975. PH fluctuation. In pytilga edul1s L. In relation to she11 movements under aerobtc and anferoble conditions. $P$. 139-149. In H. Barnea (ed.), Prog. gth Eutop. Mar. Btol. Sym. The Aberdeen Untversity Press, Aberdeen.

W1lps, $H$, and $E$. Zebe. 1976. The end-producte of anaerobic carbobydrate metaboling In the latvae of Chironomus thumpt thumin. J. Comp. Phys Lo1. 112B:263-272,

Zebe, E. 1975. In vivo-Unterauchungen thex den Glukoge-Abbeu bel Arentcola martna (Annelida, Polychaeta). J. Comp. Physiol. 101:133-145. 
Zwaen, A. de. 1977. Anaeroblc energy metaboliam 1n bivalve mollugce. Oceanogr. Har, BLol, 15:103-187.

Zwan, A. de and D.I. Zandee. $\$ 972 a$. Body dLatr1bution and ceanona changea in the glycogen content of the common oea mrasel tytilug edulis, Coip. E1ochem. Fhys 101. 43A:53-5B,

Zwaan, A. de and D.I. Zandee, 1972b. The uttlization of glycogen and accumblation of some Intermediates during anaerobion is in Mytilus edulfe $\mathrm{L}$. Comp. B1ocheth. Fhystol, 43B:47-54.

Zwan, A. de, W.J.A. Van MarrewIjk, and D.A. Holwerda. 1973. Anaeroble carbohydrate getabolism In the gea mug Bel yytilug eduLia L. Neth. J. Zool, 23:225-22B,

7waan, A. de and W.J.A. Marrewtjk. 1973a, Anaeroble glucoege degradat 1an

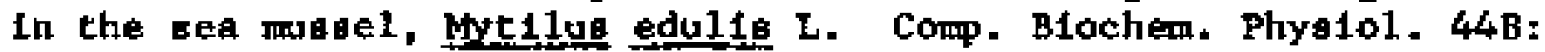
429-439.

Zwati, A, de and W,J.A, Marrew1fk, 1973b. Intracellular locelteat lon of pyrurate carboxylaee, phogphoenolpyruvate carboxyktnase, and "maltc enzyme" and the aboence of glyoxylate cycle enzyme in the bea mugael, wytilue edu11. L. Comp. BLochem. Phyolo1, 44B:1057-1066.

Zwaan, A. de, A.H.T. de Bont, and J.H.F.M. Kluytmane, 1975. Hetabolic adaptatione on the aerobic-anaerobic cramettion in the oes mogel, Hyt1lue edu1ta I. P. 121-13日. In H. Batneg (ed.), Proc, 9th Eutop. Mar. Blol. Symp. The Aberdeen Unfveratty Preas, Aberdeen.

2wan, A. de, J.H.F.M. Kluytmane, and D.I. Zandee, 1976. Facultative anaerobloste in molluses. Blochen. Soc. Symp. 41:133-168.

Zwan, A, de and T,C.M, W1jeman, 1976. Anaeroble metabolight In BIvalvia (Hollueca): characterfacteg of angeroble metabollem. Comp. Blocherm. Fhysiol. 54B:313-324. 
APPENTIX

LIST OF COMONON WAHES AND ABEREVIATIONS 


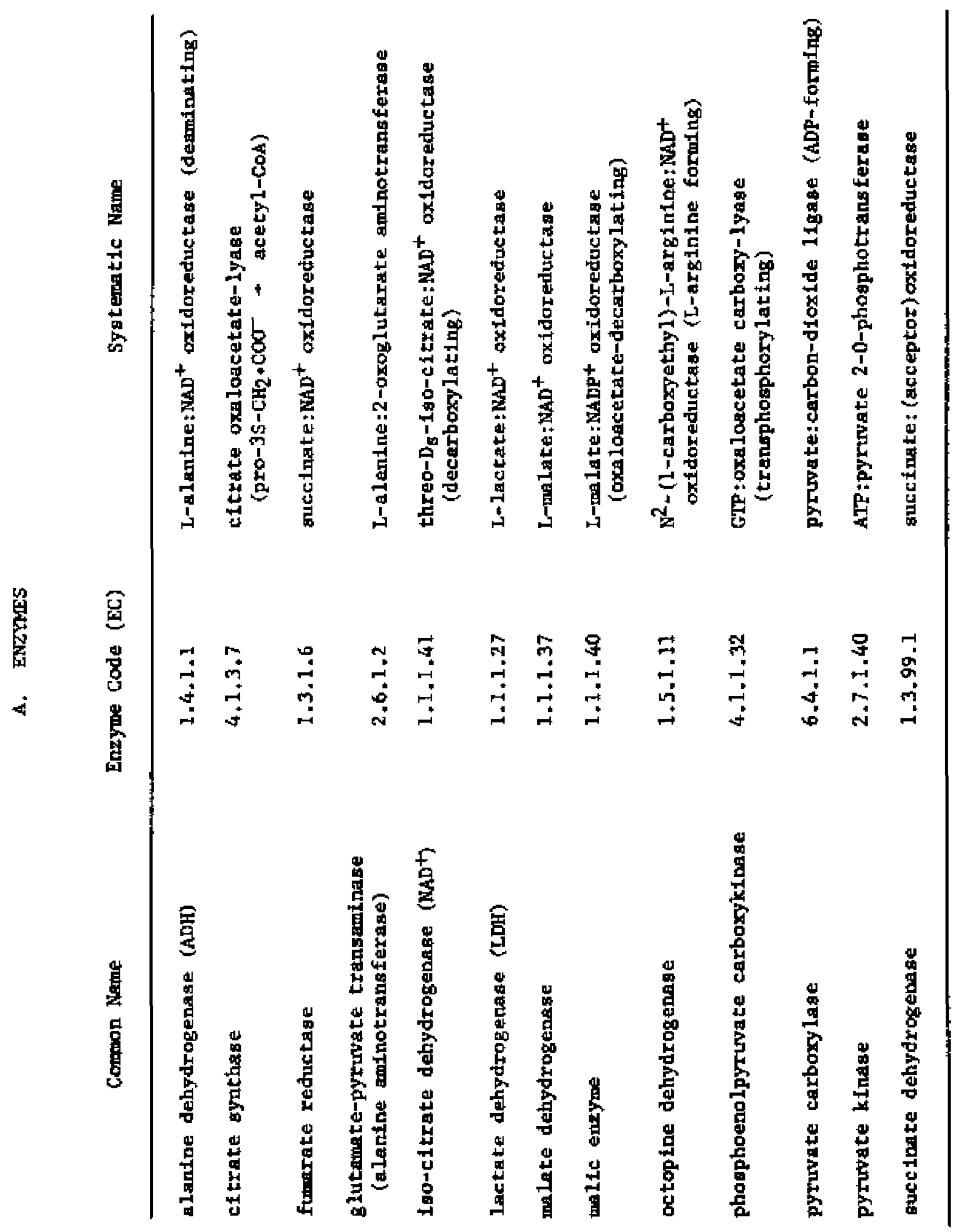


B * METABOLITES

\begin{tabular}{|c|c|}
\hline a -kGA & a-keto-gtutarate \\
\hline $1,3-d P G A$ & 1, 3-diphosphog 1ycerate \\
\hline FDP & D-fructose-1,6-d tphosphate \\
\hline F-6-P & D-fructoee-6-phosphate \\
\hline$G=1-P$ & D-glucose-1-phosphate \\
\hline $6-3 * P$ & glyceraldehyde-3-phosphate \\
\hline$G-6-P$ & D-glucoge-6-phoaphate \\
\hline DAA & oxaloacetate \\
\hline PEP & phosphoeno lpyruvate \\
\hline $2-\mathrm{PGA}$ & 2-phosphog 1ycerate \\
\hline 3-PGA & 3-phosphoglyeerate \\
\hline$\sqrt{T A}$ & volatile fatty actd \\
\hline$c_{2}$ & acetlo acid-ethanolc acid, acetate \\
\hline $\mathrm{C}_{3}$ & proplonic aeid-propanole acid, proplonate \\
\hline $180-C_{4}$ & $\begin{array}{l}\text { 1ao-butyric actd } 2 \text {-methy 1-propanolc acld, } \\
\text { Lao-butyrate }\end{array}$ \\
\hline $\mathrm{C}_{4}$ & n-butyric acid=n-butanole actd, n-butytate \\
\hline $1,90-C_{5}$ & $\begin{array}{l}\text { 180-valeric actd-3-methyl-butanole acld, } \\
\text { 1日o-valerate }\end{array}$ \\
\hline $\mathrm{C}_{5}$ & n-valerlc actd-n-pentanole actd, n-valerate \\
\hline
\end{tabular}


C. COENZYHES

ADP

ATP

GOASH

FAD

$\mathrm{FADH}_{2}$

GDP

GIP

IDP

ITP

NAD

MADH

MADP

MADPH adenos Lne diphosphate

adenos Lne triphosphate

coenzyme A

flavine adenfine dinucleotede (oxidized)

flavine adenine dinucleotide (reduced)

Guanostne dtphosphate

Euanog Ine triphosphate

Lnoatne diphoaphate

Inogltue triphogphate

nicot Enaride adenine dinucleotide (oxldized)

ntcotinamide adentne dinucleotide (reduced)

nleot1namlde-adentie dinucleotide phosphate (oxtdized)

ntcotinamide-adenlne dinucleot lde phosphate (reduced) 
D. REFEREWCES

Comblsion on BLochentcal Nomenclature, 1972, Enzyne Nomenclature, 443 p. American Elaevier Publightng Co., Ine, New Vork, N.Y.

Lehninger, A.L. 1970. B1ochemletry. 833 p. Worth Publishers, Inc, New York, N.Y.

Morrigon, R.T. and R.W. Boyd, Organle Chemlatry. 1204 p. Aliyn and Bacon, Inc., Boston. 
VITA

\section{Heng-5han Ho}

Born In Amony, Fu-Chang, ChInf, July 15, 1947, Graduated from the H1gh School of Nat Lonal TaLwan Nommal Untwera1ty, Talpel, TaIman, July 1966; B.s., Netforal Taiwan Jnfyera1ty, June 1970; M.5., North Carolina State Undvera1ty, December 1973.

Entered the School of Marine Sctence of the College of WIlliam and Mary ag a graduate gtudent In the Department of Enviromental Phystology In September 1973.

Appointed to the research etaff of the School of Pharmacy, Intveratty of Colorado in September 1979. 